Article

\title{
An Alternative to Field Retting: Fibrous Materials Based on Wet Preserved Hemp for the Manufacture of Composites
}

\author{
Hans-Jörg Gusovius * (1) Carsten Lühr, Thomas Hoffmann, Ralf Pecenka@ and Christine Idler \\ Leibniz Institute for Agricultural Engineering and Bioeconomy (ATB), Max-Eyth-Allee 100, \\ 14469 Potsdam, Germany \\ * Correspondence: hjgusovius@atb-potsdam.de; Tel.: +49-331-5699-316
}

Received: 25 April 2019; Accepted: 27 June 2019; Published: 3 July 2019

\begin{abstract}
A process developed at the Leibniz Institute for Agricultural Engineering and Bioeconomy (ATB) for the supply and processing of wet-preserved fiber plants opens up new potential uses for such resources. The processing of industrial hemp into fiber materials and products thereof is undergoing experimental research along the value-added chain from the growing process through to the manufacturing of product samples. The process comprises the direct harvesting of the field-fresh hemp and the subsequent anaerobic storage of the entire plant material. Thus, process risk due to unfavorable weather conditions is prevented in contrast to common dew retting procedures. The effects of the anaerobic storage processes on the properties of the bast part of the plant material are comparable to the results of common retting procedures. Harvest storage, as well as further mechanical processing, leads to different geometrical properties compared to the bast fibers resulting from traditional post harvesting treatment and decortication. The fiber raw material obtained in this way is well suited to the production of fiberboards and the reinforcement of polymer or mineral bonded composites. The objective of this paper is to present recent research results on final products extended by a comprehensive overview of the whole supply chain in order to enable further understanding of the result influencing aspects of prior process steps.
\end{abstract}

Keywords: industrial hemp; harvest risk; wet preservation; composite; fiberboard

\section{Introduction}

Natural fibers, in particular bast fibers from agricultural resources, have gained an increasing interest in past decades. Known from numerous applications in ancient times, hemp and flax fibers have been (re-)introduced in textile, building or automotive products [1-10]. In addition, further research has been conducted in order to utilize non-conventional fibrous biomasses, especially for the manufacturing of building products like fiber- or particleboards [11-13]. The influence of the selected raw material as well as the processing method is an essential part of implementing such alternative resources into specific product applications [14].

The legalization of industrial hemp cultivation for fiber production was followed by numerous research activities in regard to the selection of varieties and the determination of the optimal agronomic conditions for sowing, fertilization and crop management. Breeders, as well as farmers with great experience, have been accompanying these developments with new and optimized varieties (biomass yield, fiber content, multi-purpose use, cannabinoid content) [15,16]. Research and development on processing technologies as well as on industrial applications of fibers and other intermediates of bast fiber crops was halted in many regions worldwide for a long time. The main reasons have been both the shift from natural fibers to petroleum based raw materials as well as legislative constraints, especially in case of 
hemp. The changed legal situation and economic support on European and national level enabled the reestablishment of the growing and processing of natural fiber raw materials in Germany in the middle of the 1980s (flax) as well since 1996 (hemp). Thereafter, similar developments have been reported from other countries in Europe, North America and Asia.

The renaissance of hemp cultivation in Europe has resulted in an acreage of currently 43,000 ha. Similar developments can be observed in e.g., Canada or China [17]. Although interest in and production of cannabinoids as well as hemp seeds are currently accelerating this development, there is still great industrial interest in the use of natural fibers in materials. Apart from their applications in pulp and paper, and insulation, technical textiles, especially composites, in the automotive industry is one of the major markets for hemp fibers. For example, a 30\% increase in the use of bast fibers such flax and hemp was recorded in this industry from 2005 to 2012 [18]. Further expectations are known from the apparel market $[19,20]$ and for sustainable building applications [21,22].

In general, all developments are based on the traditional value-added chain consisting of field drying and retting of bast fiber crops followed by mechanical processing of dry straw by means of decortication and its separation in fiber and non-fibrous fractions (e.g., shives/hurds). This traditional processing line is characterized by several challenges such as available harvesting capacities, cost-income relationships between cultivation of fiber plants and marketing of manifold products as well as quality management [23-29].

The weakening or degradation of the structures which are cementing fiber elements to each other to other stem tissues is a necessary step prior to any mechanical separation of fiber containing bast from the rest of the plant. Different procedures like microbiological, chemical or physical retting are known and well established in practice, while others have been under investigation or subject to research [30]. A traditional, but most common approach for this pretreatment step is field or dew retting [31-39]. However, the homogeneous properties of natural fibers as requested by the industry are hard to control due to the high weather dependency of field retting. Alternative procedures are known or have been developed to overcome this challenge but are not used due to environmental issues (water retting) or high efforts in relation to the costs of their industrial realization (e.g., steam explosion).

At this point, research \& development activities, in particular at the Leibniz Institute for Agricultural Engineering and Bioeconomy (ATB), have started to investigate alternatives in order to simplify the harvesting operations as well to reduce the weather dependency of the supply procedures in agriculture [40]. Already in the early 1990s, Dutch scientists carried out research for alternative fiber resources in the pulp and paper industry. Direct harvesting using forage harvesters and subsequent wet preservation has been favored due to regional circumstances [41-43]. The results of further investigations indicated advantages in agricultural production and suitable raw material properties of wet preserved hemp for material applications [44]. The background for this type of preservation is widely existing knowledge, as is the practice of fodder ensiling for animal nutrition. In principle, related research work is also carried out to assess the influence of supply processes on the resulting product properties [45]. In particular, a subject of recent research has been mechanical processing prior the utilization of wet preserved biomass [46].

Based on the state of knowledge and previous research and development work, two essential process lines can be defined for the harvesting of hemp and for provision of raw materials for further processing (Figure 1). Specific challenges, as well as research activities to overcome them are described in detail below. 


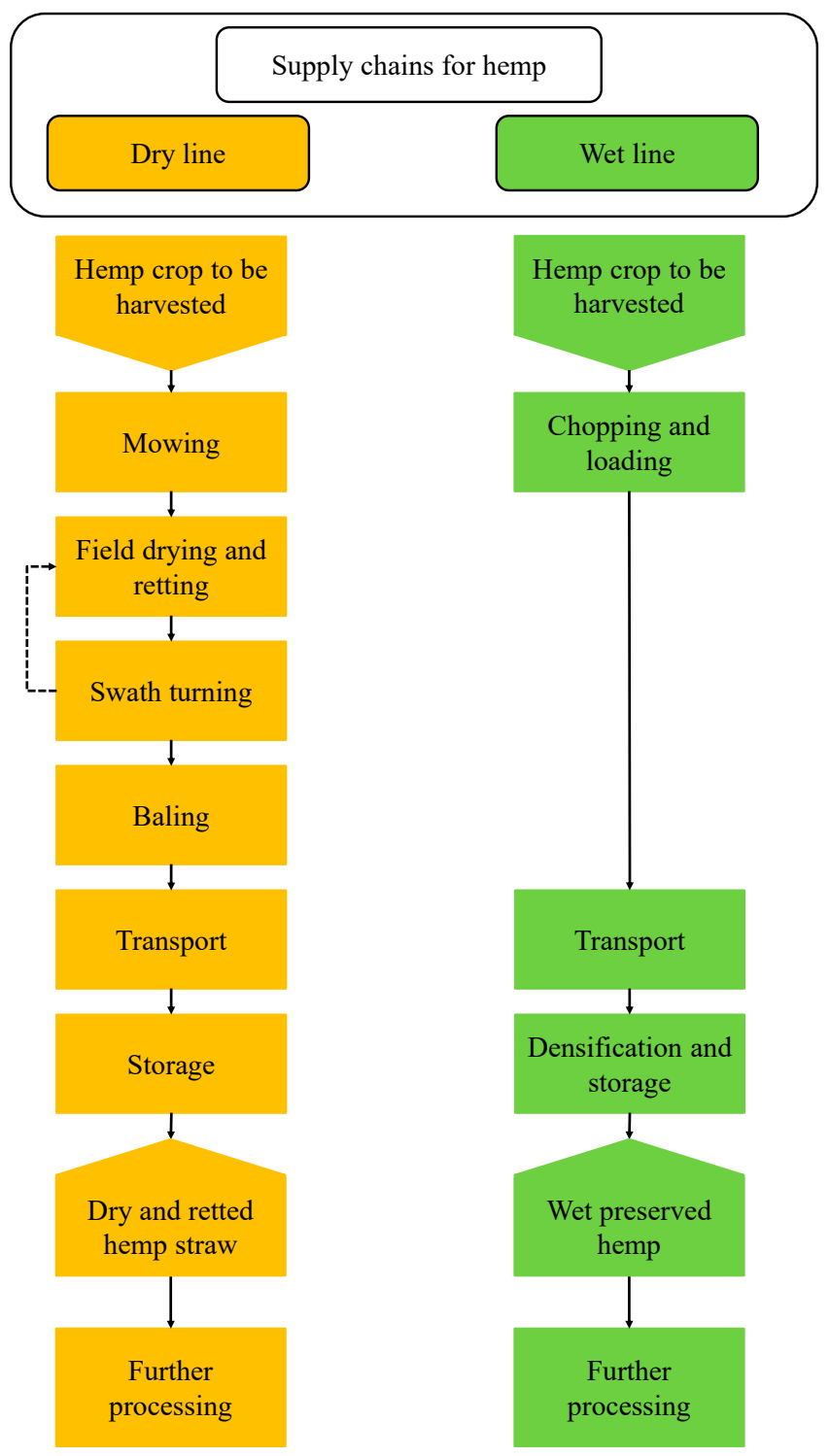

Figure 1. Basic design of process lines for hemp harvesting.

\section{Materials-Raw Material Supply}

\subsection{Growing and Harvesting}

Since 1999, hemp has been cultivated in small field plots as part of the research activities of the ATB in Potsdam. In general, the cultivation itself was not scientifically planned and carried out, but rather operated under simplified operating conditions in order to secure the supply of raw materials for specific R\&D projects with regard to subsequent storage and processing methods. This was applied in particular to a national network project that focused on new supply chain strategies and processing methods for domestic fiber plants ("FENAFA-Integrated supply-, processing and manufacturing procedures for natural fibre materials", 2009-2014) as well as to the collaborative EU-FP7 project "Multipurpose hemp for industrial bioproducts and biomass" ("MultiHemp", 2012-2017).

Usually, the sowing of hemp took place in early to mid of May at a rate of $50 \mathrm{~kg} \mathrm{ha}^{-1}$. The selection of the variety was based on the yearly availability of seeds on the market, in particular of small quantities for scientific purposes. Due to this fact, different varieties have been grown over the years. Fertilization was generally carried out according to previously determined soil conditions, but never more than on an $80 \mathrm{~kg} \mathrm{ha}^{-1}$ nitrogen basis. 
Following the growing season, hemp is harvested at different periods beginning from August until November. The preferred procedure has always been selected according to the corresponding task of the research project for the subsequent further processing of the raw material. The main focus within the two mentioned projects has been the harvest of the whole crop biomass using forage harvesters and its subsequent wet preservation ("ensiling") [47] (Figure 2).

A

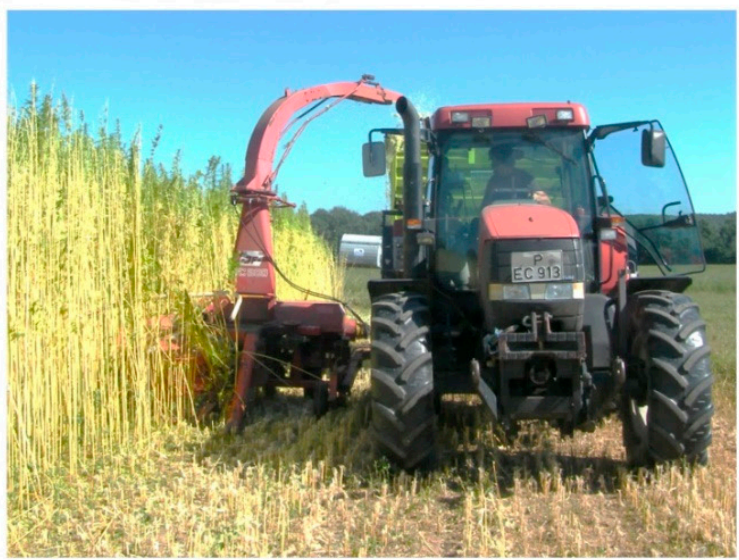

C

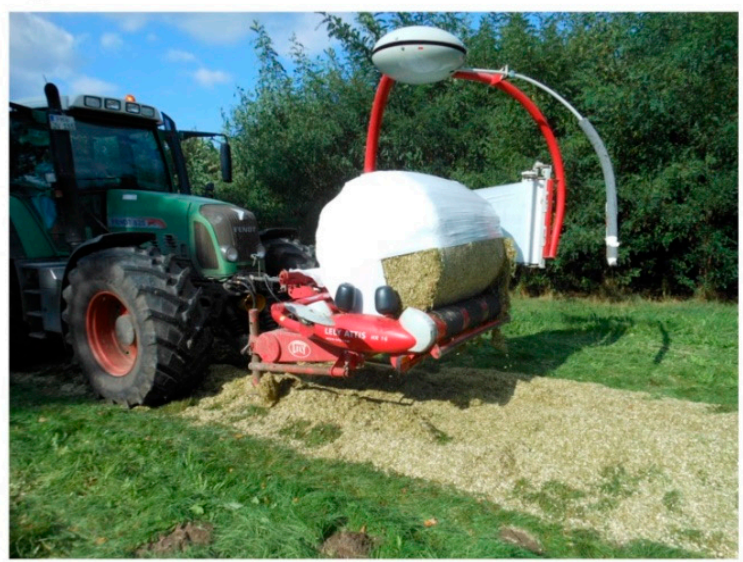

B

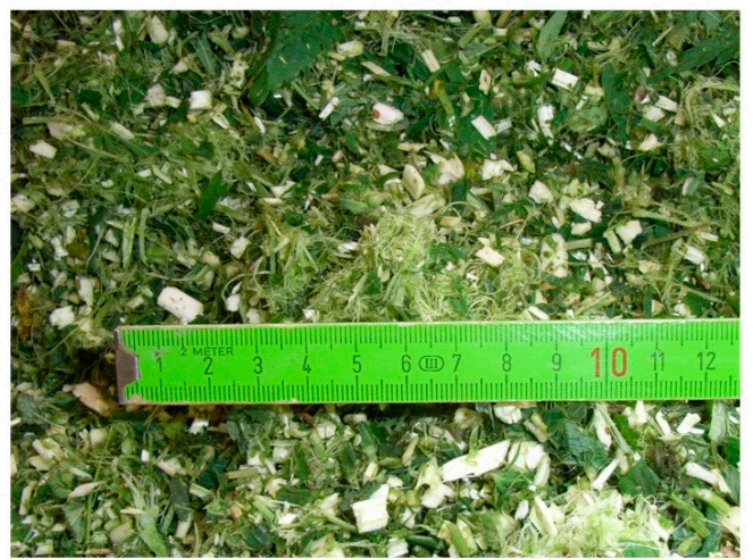

D

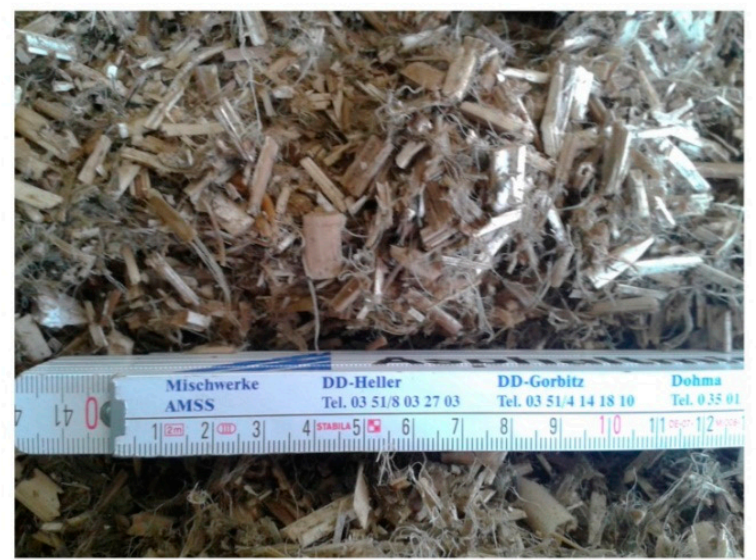

Figure 2. Harvesting of hemp with forage harvesters (A) for subsequent wet preservation storage (C), fresh chopped hemp whole crop material (B), wet preserved hemp whole crop material (D).

The background of this specific supply chain has been fundamental research activities on an alternative process chain for the utilization of hemp biomass for the manufacture of technical products, such as fiberboards, beginning from the late 1990s [40,47,48]. The key aspects of the research work were a reduction of the technical expenditure for harvesting and processing as well as a reduction of the harvest risk. Extensive investigations of the available harvesting technology have shown that conventional agricultural machinery typically used for fodder production can be used for harvesting hemp without significant modifications [48]. However, the weather risk is an essential aspect in the provision of hemp raw materials for traditional processing. Partially unfavorable weather conditions in the post-harvest period result in varying straw qualities and, in some cases, total losses $[36,43,49]$.

\subsection{Weather Related Risk of Harvesting Hemp}

Common kinds and types of machines for harvest operations are used according to available equipment and the targeted utilization of harvested biomass [25,26]. Many different technologies have been developed along with the expansion of this growing area in past years. In general, two process lines are known of which the so-called straw line ("dry line", Figure 1) is most practiced worldwide. 
The related procedure consists of mowing and stem shortening by different cutting devices and dropping the biomass on the ground. The optional seed harvest can be carried out either before or during mowing. The subsequent time period shall enable field drying and dew retting in order to reach (a) a moisture content allowing quality preserving storage of straw and at the same time (b), the biological degradation of fiber gluing substances. This period is characterized by a high weather-related procedure risk especially when hemp is harvested for dual-purpose (fiber and seed). As seed ripening occurs late in August or even in September in many regions of Europe, the required time available for harvesting of straw with a quality preserving dry matter (DM) content of $\leq 18 \%$ is getting shorter and shorter [50].

Similar to plant growing in agriculture, harvesting operations are affected by climatic conditions as well. Field operations such as mowing, and in particular natural drying on the field, are only possible in times of favorable weather conditions. The time available is therefore a limiting factor for the planning of such operations. The term "available working capacity" is defined similar to a number of available field working hours in a relevant period in order to evaluate and compare certain field operations with regard to their weather-related procedure risk. In particular, for new technology developments this issue has to be evaluated in detail in order to carry out comprehensive and comparative assessment.

The weather-related procedure risk for the usual harvest period of industrial hemp straw has been estimated based on real measurements of the moisture content development, the generation of a model including respective climate data, and finally simulation with long term weather data [50]. Hoffmann et al. [51] have used a similar procedure to assess the weather-related procedure risk for harvesting of hemp in winter. In these cases, the model simulation has been carried out with long-term climate data from selected regions in East Germany. The available number of working hours for the gathering (baling) of dry hemp straw is limited to $13-30 \mathrm{~h}$ per month in the usual harvest period in August and September. A swathless deposition of the hemp crop on field ground, as realized by cutter bars, seems to be favorable compared to the placement of a swath by other harvesting technologies. The available time is reduced by $10-20 \mathrm{~h}$ when mowing or retting is delayed to October. Available time periods can be enlarged when suitable harvesting technologies for an improved moisture release, e.g., field conditioning, are used. In contrast, a winter harvest can enable an even higher number of available hours up to $55 \mathrm{~h}$ (Figure 3).

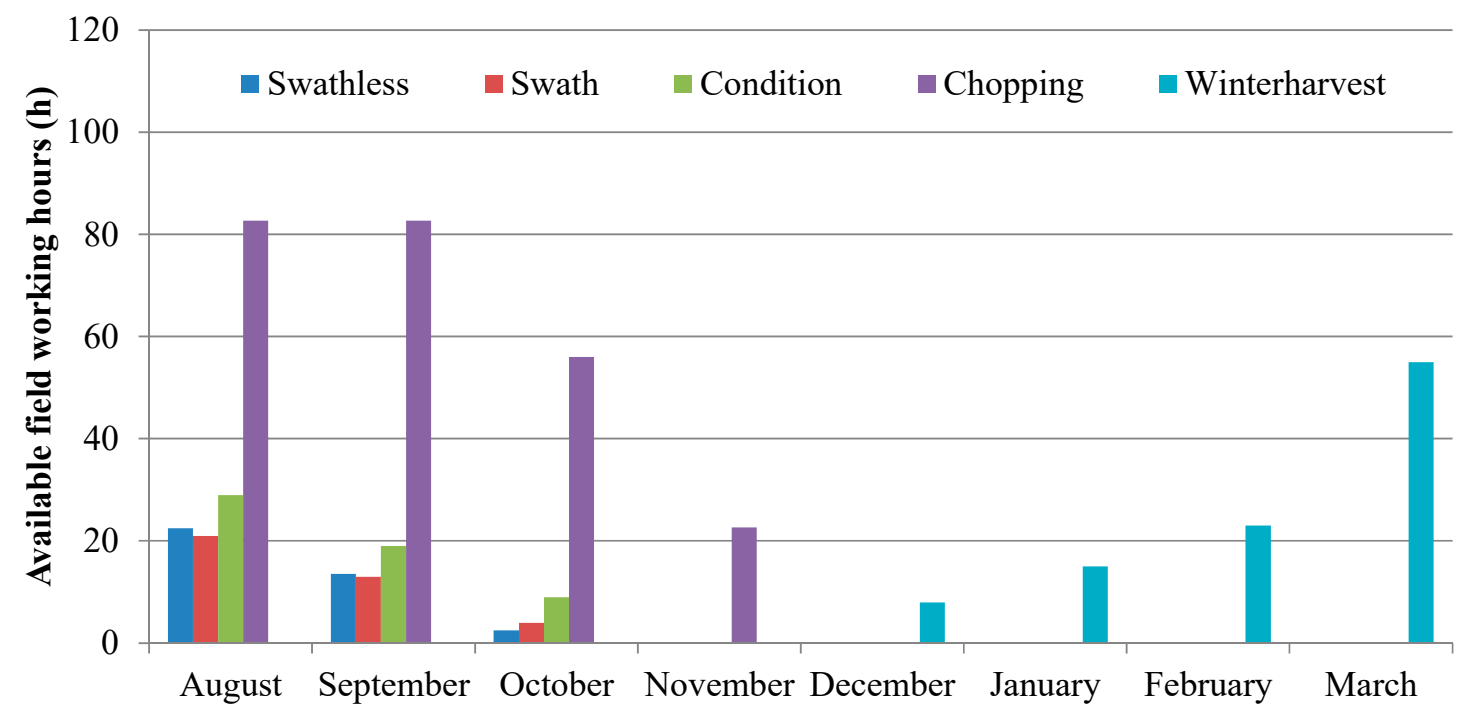

Figure 3. Available field working hours in given time periods for the harvest of storable hemp raw materials. Values for dry line procedures already published in Gusovius et al. and Hoffmann et al. [50,51].

Harvesting of hemp in the winter period can be an option in terms of unfavorable weather conditions in the usual time periods and seems to have potential in terms of the quality and utilization of the resulting biomass [20,52]. 
In contrast to the above-mentioned straw line, direct chopping from the plant stand and subsequent wet preservation might be an alternative for a quality preserving storage of fiber crops. The remarkable reduction of the weather-related procedure risk can be determined by the significantly higher number of available working hours in the usual harvest period. These are, based on modelling with site specific weather data, around 50-100\% higher compared to the other harvesting procedures based on field drying [53] (Figure 3). Thus, the weather-related procedure risk is significantly reduced when chopping, and subsequent wet preservation of the harvest yield is applied.

\subsection{Storage Procedures}

The harvested and chopped biomass including all plant components (whole stems, leaves, flowers respectively panicles with seeds) is directly transported to a stationary compaction unit and stored under anaerobic conditions in bales, tubes or concrete silos. The procedure and used machinery are similar to conventional harvest operations for animal fodder and does not require specific technical modifications. In the case of freshly chopped hemp plants, different procedures for a proper densification as well as immediate sealing with typical silage wrappings have been tested in the past $[26,48]$. A storage system in bunker silos is highly dependent on the availability of such facilities, while ensiling in bales (Figure 2C) or tubes has become more and more popular. Even the machine combinations for chopping and immediate baling (partly including sealing) are available on the market and were evaluated at hemp harvests in the Netherlands within the EU project "MultiHemp" [54].

Experience with the processes has shown that a trouble-free use of standard farm technologies is also possible for storage. For safe preservation without the risk of spoilage, air inclusions as well as damage to the silage wrappings must be avoided.

\section{Experimental Procedures}

\subsection{Wet Preservation}

The principle of wet preservation by natural fermentation during anaerobic storage is the metabolization of natural sugar (mainly glucose and fructose) under anaerobic conditions by means of microbial activity, especially by lactic acid bacteria (LAB), to a mixture of acids. As a result, the $\mathrm{pH}$-value decrease, and a breakdown of carbohydrates by undesirable microorganisms is prevented. Sugar and dry matter (DM) contents are important parameters for the wet preservation. According to Wieringa and Haan [55], at least $75 \mathrm{~g}$ sugar / kg DM is necessary for lactic acid fermentation. Carbohydrates, e.g., glucose, sucrose or fructose, are particularly easy to convert to lactic acids by LAB. For successful preservation, the DM content of the material should not be below 20\% [56]. In order to obtain rapidly anaerobic conditions in the silo, the biomass must be compacted. Therefore, the DM content is of special importance. At $40 \%$ DM content the compressibility decreases considerably, at DM contents lower than $20 \%$ the formation of silage effluent has to be expected [56]. The dry matter losses should not be higher than the unavoidable process losses of $10 \%$ DM [56].

The main objective of the wet preservation of hemp is to keep essential quality properties of the raw material needed for further processing and utilization. In this case, it means that in particular the cell wall component cellulose, which is responsible for its excellent mechanical characteristics, should not be degraded more than other the cell components.

Hemicellulose compounds are defined as being responsible for the link of fiber to fiber as well as fiber to other tissues should they be degraded in the course of preservation. A similar effect to dew/field retting is to be expected and enables an easier defibration in following mechanical processing of the raw material [57-59]. This refining effect results in thinner fiber elements with a higher relative surface area and is preferable for an improved fiber-matrix-adhesion in further applications [60].

Poor input properties of crop material (low sugar content, low content of LAB, low DM content) and unfavorable weather conditions at harvest time can be partially compensated by additives [41]. 
For this purpose, chemical, biological and sugar-containing ensiling and preserving agents from different producers are available for feed preservation [61].

For the preservation of hemp chaff different biological and chemical additives, designed for feed preservation, were tested in model trials and at practice scale. The preservation results were evaluated for: biological additives (BIO-SIL, KOFASIL ${ }^{\circledR}$ LIFE "M", SILASIL ENERGY G, SILOSTAR GRAS), acidic chemical additives (lactic acid, LUPROSIL, FORAFORM) and alkaline chemical additives (caustic soda). However, all additives and also trials without additives led to well preserved hemp [47,48].

\subsection{Chemical Analysis}

After harvesting the hemp, chaff was analyzed for DM, pH and sugar [62] as well as for the carbohydrates cellulose, hemicellulose and lignin [63]. Furthermore, in order to evaluate the preservation process, the following parameters were investigated at different times during the anaerobic storage: alcohols (ethanol, propanol) and volatile fatty acids (VFA) (acetic, lactic, propionic, i-butyric, n-butyric, i-valeric, n-valeric and capronic acid) [64]. The DM losses were calculated according to Weissbach, and Kuhla [65] (Table 1).

Table 1. Methodical details for the analysis of hemp raw materials.

\begin{tabular}{|c|c|c|c|c|}
\hline Material & Parameter & Unit & Methods & References \\
\hline \multirow{6}{*}{$\begin{array}{l}\text { Fresh chopped and } \\
\text { wet preserved } \\
\text { hemp }\end{array}$} & Dry matter & $\% \mathrm{FM}$ & Gravimetry & $\begin{array}{l}\text { VDLUFA MB Vol. } \\
3 \text { Chapter } 3.1 \text { [62] }\end{array}$ \\
\hline & $\mathrm{pH}$ & - & $\begin{array}{l}\text { Electrode Sen Tix } \\
41\end{array}$ & $\begin{array}{l}\text { VDLUFA MB Vol. } \\
3 \text { Chapter } 18.1 \text { [62] }\end{array}$ \\
\hline & Sugar & $\% \mathrm{DM}$ & Reducing sugar & $\begin{array}{l}\text { VDLUFA MB Vol. } \\
3 \text { Chapter 7.1.1 [62] }\end{array}$ \\
\hline & Cellulose & $\% \mathrm{DM}$ & \multirow{3}{*}{$\begin{array}{l}\text { Ankom2000 Fiber } \\
\text { Analyser system, } \\
\text { filter bag } \\
\text { technology }\end{array}$} & \multirow{3}{*}{$\begin{array}{l}\text { Herrmann et al. } \\
\text { (2012) [63] }\end{array}$} \\
\hline & Hemicellulose & $\% \mathrm{DM}$ & & \\
\hline & Lignin & $\% \mathrm{DM}$ & & \\
\hline \multirow[t]{3}{*}{$\begin{array}{l}\text { Wet preserved } \\
\text { hemp }\end{array}$} & $\begin{array}{l}\text { Ethanol, propanol, acetic, } \\
\text { propionic, i-butyric, n } \\
\text {-butyric, i-valeric, } \\
\text { n-valeric, capronic acids }\end{array}$ & $\% \mathrm{DM}$ & $\begin{array}{c}\text { Gas } \\
\text { chromatography }\end{array}$ & $\begin{array}{l}\text { Herrmann et al. } \\
\text { (2011) [64] }\end{array}$ \\
\hline & Lactic acid & $\% \mathrm{DM}$ & $\begin{array}{c}\text { Liquid } \\
\text { chromatography }\end{array}$ & $\begin{array}{l}\text { Herrmann et al. } \\
\text { (2011) [64] }\end{array}$ \\
\hline & Mass losses & $\% \mathrm{DM}$ & Calculation & $\begin{array}{l}\text { Weissbach and } \\
\text { Kuhla (1995) [65] }\end{array}$ \\
\hline
\end{tabular}

FM—fresh matter, DM—dry matter.

\subsubsection{Characterization of Fresh Chopped Raw Material}

To determine a favorable harvest period, sugar and DM contents in different hemp varieties were analyzed in various years in the period from the end of July to mid-September [47]. During the development of the hemp plant on the field, sugar and DM contents developed differently in the tested hemp varieties. In many varieties e.g., Bialobrzeskie, Fedora 17, Felina 32, Kompolti Hybrid TC, Lovrin 110 and USO-34, the highest sugar levels develop until mid-August and then decrease again. In some varieties, the highest levels of sugar are found only in mid-September (Kompolti, Uniko B). In most varieties, the DM reaches in mid-September values of about $40 \%$, which are too high for an optimum compaction. If hemp is to be wet preserved, a harvest period between August and September with regard to the sugar and DM content is suitable for many varieties.

In the projects "FENAFA" and "MultiHemp", hemp of different varieties, was regularly cultivated. The harvested hemp chaff was analyzed for different parameters before wet preservation and storage 
(Table 1). In the harvesting period from early September to early October, the contents of the examined parameters of the chopped whole plants showed large spans in the different varieties and harvest years (Table 1). The DM contents varied from 29.5 to $40.5 \%$ and the sugar contents from 1.2 to $3.9 \%$ DM. In all varieties the sugar contents are importantly lower than the necessary content for a successful preservation from amount of 7.5\% DM. However, de Maeyer and Huisman [42] and Huismann et al. [66] were also able to confirm experimentally that hemp chaff can be preserved by anaerobic storage.

The spread in the fiber fractions also showed great differences: cellulose (39-61\% DM), hemicellulose (6-16\% DM) and lignin (8-12\% DM) (Table 2). Results for the contents of these parameters can also be found in the literature. De Maeyer and Huisman [41] found in hemp chaff after harvest at mid-September the same content of cellulose and hemicellulose from 47\% DM and $14 \%$ DM, respectively, as the authors. However, they found a higher lignin content with $15 \%$ DM. Also Cappelletto et al. [67] analyzed the dried hemp stems without leaves and flowers and found partly higher contents: cellulose contents of $49-54 \%$ DM, higher hemicellulose contents of $21-27 \%$ DM and higher contents for lignin 11-14\% DM. Similarly, high cellulose contents of $65 \%$ DM were found by van der Werf and van Geel [68] in hemp bast. In comparison to our findings, these higher levels can be explained by the non-leaf and flowerless study material described by the authors mentioned above.

Table 2. Dry matter (DM), sugar and fiber fractions in hemp of various varieties at different harvest times $(n=3)$.

\begin{tabular}{ccccccc}
\hline $\begin{array}{c}\text { Hemp } \\
\text { Variety }\end{array}$ & Harvest Date & $\begin{array}{c}\text { DM \% } \\
\text { FM }\end{array}$ & $\begin{array}{c}\text { Sugar \% } \\
\text { DM }\end{array}$ & $\begin{array}{c}\text { Cellulose \% } \\
\text { DM }\end{array}$ & $\begin{array}{c}\text { Hemicellulose } \\
\text { \% DM }\end{array}$ & $\begin{array}{c}\text { Lignin \% } \\
\text { DM }\end{array}$ \\
\hline Fedora 17 & 1 October 2009 & 38.80 & 2.01 & 38.93 & 15.81 & 8.75 \\
USO-34 & 28 September 2010 & 28.50 & 1.58 & 49.76 & 8.33 & 7.96 \\
Santhica 27 & 2 September 2011 & 29.25 & 3.89 & 44.50 & 13.04 & 7.84 \\
Santhica 27 & 12 September 2012 & 32.21 & n.e. & 53.47 & 7.29 & 11.33 \\
Fedora 17 & 25 September 2013 & 36.05 & 1.75 & 54.21 & 6.24 & 10.90 \\
Futura 75 & 28 September 2014 & 40.54 & 1.16 & 60.66 & 10.43 & 11.60 \\
\hline \multicolumn{7}{c}{ n.e.-not examined. }
\end{tabular}

Experiments with a further addition of extra-cellular enzymes were carried out in order to investigate the influence of enzymes on the decomposition of fiber cementing cell wall structures (hemicellulose) [69] as well the reduction of the silage typical odor [70]. Therefore, propionic acid (LUPROSIL), a pectolytic enzyme (NATUZYM MAX) and the combination of propionic acid and the enzyme were tested [71]. Various parameters and mass losses were determined before and after preservation.

\subsubsection{Characterization of Wet Preserved Hemp}

As an example, the influence of different additives during the one-year preservation in $120 \mathrm{~L}$ barrels of the hemp variety Santhica 27 on the chemical properties will be described (Table 3).

After one year of preservation, the $\mathrm{pH}$ values in all test series are in the acidic range. After only 6 months, all additives cause a decrease of the $\mathrm{pH}$-value below 5 . The additions of LUPROSIL and NATUZYN MAX led to the lowest $\mathrm{pH}$-values. However, even without additives all hemp samples had a pH below 6 after one year of storage. In all test series the sugar content decreased, and acids were formed. After one year of storage, the sum of VFA had 25.2\% DM, the highest after the addition of acid and the enzymes. As expected, propionic acid had in this test series, as well as in the test series after the addition of LUPROSIL, the largest amount of all acids. In contrast, acetic acid dominated in the test series without additives or with enzyme addition. In model experiments, de Maeyer, and Huisman [43] found similar contents of lactic and acetic acid after 6 months in wet preserved hemp without additives. In contrast to the findings of the authors, these preservations of the whole hemp plant were almost butyric acid-free. 
Table 3. Analyses of hemp chaff after harvest at 2 September 2011 and after 6 and 12 months of anaerobic storage with and without additives $(n=3 *)$.

\begin{tabular}{|c|c|c|c|c|c|c|c|c|c|c|c|c|c|}
\hline \multirow{3}{*}{$\begin{array}{c}\text { Parameter } \\
\text { Additives } \\
\text { Storage time }\end{array}$} & \multicolumn{2}{|c|}{ Dimension } & \multicolumn{2}{|c|}{ Santhica } & \multicolumn{3}{|c|}{ Santhica } & \multicolumn{3}{|c|}{ Santhica } & \multicolumn{3}{|c|}{ Santhica } \\
\hline & - & & Without & & & UPROS & & & UZYM & & LUPRC & and $\mathrm{N} A$ & M MAX \\
\hline & months & 0 & 6 & 12 & 0 & 6 & 12 & 0 & 6 & 12 & 0 & 6 & 12 \\
\hline $\mathrm{DM}$ & \% FM & 29.25 & 28.19 & 27.23 & 28.86 & 28.49 & 27.48 & 29.87 & 27.78 & 26.90 & 29.04 & 28.75 & 26.42 \\
\hline $\mathrm{pH}$ & - & 6.87 & 6.30 & 5.82 & 5.14 & 4.86 & 4.49 & 6.86 & 4.75 & 4.43 & 5.39 & 4.39 & 4.19 \\
\hline Sugar & $\% \mathrm{DM}$ & 3.89 & n.e. & 0.21 & 3.83 & n.e. & 0.76 & 3.70 & n.e. & 1.16 & 4.31 & n.e. & 1.81 \\
\hline Cellulose & $\% \mathrm{DM}$ & 44.50 & 49.04 & 58.34 & 42.83 & 44.53 & 56.56 & 41.38 & 44.32 & 47.08 & 41.47 & 41.92 & 48.13 \\
\hline Hemicellulose & $\% \mathrm{DM}$ & 13.04 & 11.76 & 4.84 & 17.74 & 10.30 & 3.80 & 15.37 & 8.28 & 5.06 & 16.16 & 12.51 & 4.79 \\
\hline Lignin & $\% \mathrm{DM}$ & 7.84 & 7.70 & 10.83 & 7.95 & 9.41 & 9.74 & 7.07 & 8.63 & 11.67 & 7.52 & 8.45 & 10.63 \\
\hline Ethanol & $\% \mathrm{DM}$ & n.e. & 0.69 & 1.18 & n.e. & 0.26 & 0.73 & n.e. & 0.69 & 3.02 & n.e. & 0.41 & 1.82 \\
\hline Propanol & $\% \mathrm{DM}$ & n.e. & 0.08 & 0.47 & n.e. & 0.04 & 0.12 & n.e. & 0.02 & 0.19 & n.e. & 0.04 & 0.21 \\
\hline Acetic acid & $\% \mathrm{DM}$ & n.e. & 1.74 & 10.84 & n.e. & 1.24 & 4.68 & n.e. & 1.56 & 8.39 & n.e. & 1.33 & 6.74 \\
\hline Lactic acid & $\% \mathrm{DM}$ & n.e. & 1.52 & n.d. & n.e. & 3.76 & 4.05 & n.e. & 6.34 & 7.02 & n.e. & 4.52 & 5.78 \\
\hline Propionic acid & $\% \mathrm{DM}$ & n.e. & 0.17 & 2.49 & n.e. & 4.01 & 12.42 & n.e. & 0.20 & 0.89 & n.e. & 3.83 & 12.31 \\
\hline i-butyric acid & $\% \mathrm{DM}$ & n.e. & n.d. & 0.63 & n.e. & n.d. & n.d. & n.e. & n.d. & n.d. & n.e. & n.d. & 0.03 \\
\hline n-butyric acid & $\% \mathrm{DM}$ & n.e. & 1.13 & 6.45 & n.e. & 0.01 & 0.02 & n.e. & 0.63 & 3.25 & n.e. & 0.01 & 0.22 \\
\hline i-valerian acid & $\% \mathrm{DM}$ & n.e. & 0.03 & 0.57 & n.e. & 0.02 & n.d. & n.e. & n.d. & n.d. & n.e. & 0.01 & 0.03 \\
\hline n-valerian acid & $\% \mathrm{DM}$ & n.e. & n.d. & 0.34 & n.e. & n.d. & n.d. & n.e. & n.d. & n.d. & n.e. & n.d. & 0.01 \\
\hline Mass losses & $\% \mathrm{DM}$ & n.e. & 2.85 & 2.97 & n.e. & 2.61 & 2.64 & n.e. & 2.79 & 2.91 & n.e. & 2.60 & 2.69 \\
\hline
\end{tabular}

${ }^{*} n=2$ in all test series at the storage time 0 months ${ }^{* *}$ Sum of acetic, lactic, propionic, i-butyric, n-butyric, i-valeric, n-valeric and capronic acid. n.d.-not detectable; n.e. - not examined;

FM—fresh matter; DM—dry matter; VFA—volatile fatty acids. 
With regard to the content of hemicellulose, there was a clear decrease over the storage period of 12 months (Table 3). However, the analysis of the content of cellulose revealed partly contradictory results. The apparent increase in cellulose, especially for a storage period of one year, cannot be explained by biological processes during storage. On the one hand, the existing analysis models of the substance analysis reflect the relative relationship of the substance components to one another. On basis of the presented data it can be assumed that a higher purity of the cellulose component can be expected with increasing storage time. On the other hand, the results can also be attributed to the very inhomogeneous starting material, consisting of shives, fiber containing bast, and leaf components.

\subsection{Further Raw Material Properties}

\subsubsection{Odor}

If the preservation of hemp is to be carried out inexpensively without additives, the high contents of butyric acids, in particular, should be considered. The odor of butyric acid could negatively influence further processes. The extent to which high butyric acid contents influence the odorant concentration [72] and the hedonic odor [73] was investigated on hemp preserves of the variety USO-34 (harvest at 28 September 2010) after addition of LUPROSIL and NATUZYM MAX as well as without additive after 2 and 4 weeks and after 6 months of the anaerobic storage (Table 4). The results showed that high odor concentrations do not necessarily occur in samples with high total acid and/or high butyric acid and/or high alcohol concentrations. The odor impression of all samples was between -1.0 and +1.0 , and is described as neither pleasant nor unpleasant.

Table 4. Odor concentration and hedonic odor of wet preserved hemp of the variety USO-34 (harvest at 28 September 2010) at different times of anaerobic storage, depending on various additives $(n=2)$.

\begin{tabular}{|c|c|c|c|c|c|c|c|c|c|c|}
\hline \multirow{2}{*}{$\begin{array}{l}\text { Parameter } \\
\text { Additives }\end{array}$} & \multirow{2}{*}{$\begin{array}{c}\text { Dimension } \\
-\end{array}$} & \multicolumn{3}{|c|}{ USO-34 } & \multicolumn{3}{|c|}{ USO-34 } & \multicolumn{3}{|c|}{ USO-34 } \\
\hline & & \multicolumn{3}{|c|}{ Without } & \multicolumn{3}{|c|}{ LUPROSIL } & \multicolumn{3}{|c|}{ NATUZYM MAX } \\
\hline Storage time & months & 0.5 & 1 & 6 & 0.5 & 1 & 6 & 0.5 & 1 & 6 \\
\hline Sum of VFA * & $\% \mathrm{DM}$ & 3.11 & 3.92 & 10.02 & 7.84 & 6.71 & 10.54 & 6.57 & 6.41 & 9.63 \\
\hline Sum of butyric acid $* *$ & $\% \mathrm{DM}$ & 0.50 & 0.75 & 3.86 & 0.06 & n.d. & 0.23 & 1.28 & 2.42 & 6.01 \\
\hline Sum of alcohols ${ }^{* * *}$ & \% DM & 1.00 & 0.96 & 0.75 & 0.33 & 0.41 & 0.46 & 2.30 & 2.75 & 1.99 \\
\hline Odour & $10^{3} \mathrm{GE}_{\mathrm{E}} / \mathrm{m}^{3}$ & 364.91 & 516.06 & 421.60 & 325.10 & 250.696 & n.e. & 729.82 & 386.61 & 546.75 \\
\hline Hedonic odour & -4 to +4 & +0.42 & -0.21 & +0.33 & +0.08 & -0.04 & n.e. & +0.25 & \pm 0.00 & +0.04 \\
\hline
\end{tabular}

* Sum of acetic, lactic, propionic, i-butyric, $\mathrm{n}$-butyric, i-valeric, $\mathrm{n}$-valeric and capronic acid. ${ }^{* *}$ Sum of i-butyric acid and n-butyric acid. ${ }^{* *}$ Sum ethanol and propanol. n.d.—not detectable, n.e.—not examined.

\subsubsection{Structural Characterization}

The structure of the hemp chaff remained largely preserved during the wet preservation. This essentially concerns the structural preservation of the composition of the chopped crop resulting from harvesting and cutting. After removal from the silo (e.g., tube or bale), the previously compacted material can be easily loosened up and continuously fed to further mechanical processing (Figure 2B,D).

In addition to the determination of the metabolic rate, analyses of the structural alteration of the plant material through or during preservation could also be carried out using SEM type Phenom Pro (Phenom World-Thermo Fisher Scientific; Eindhoven, Netherlands). Images clearly show that the microbial activity in the course of the storage process leads to the dissolution of the middle lamella connecting the individual fiber elements (Figure 4). Based on the geometric dimensions, it can be concluded that fiber bundles occurring in the fiber bast due to growth can be resolved to single fiber elements.

Selected geometrical and mechanical properties of hemp chaff were evaluated in the course of the project "FENAFA" after harvest and during the anaerobic storage [71,74]. It became clear that the wet preservation has a significant effect on these parameters. The authors found that during the 12 months of storage, the fineness of the fiber bundle collectives increased. Direct correlations with the degradation of fiber-cementing substances in the middle lamella (hemicellulose) during wet 
preservation can be assumed. Measurements of tensile properties at a fiber bundle level clearly showed a decreasing property level over storage time. Conclusions in connection to other publications can only be drawn to a limited extent, as the details of the methods used by respective researchers are unclear [41]. The method used for the determination of mechanical properties significantly influences the results of such measurements. In particular, the decreasing cohesion of the central lamella structure can lead to lower values with respect to this property for a given clamping length in common measuring methods [75].
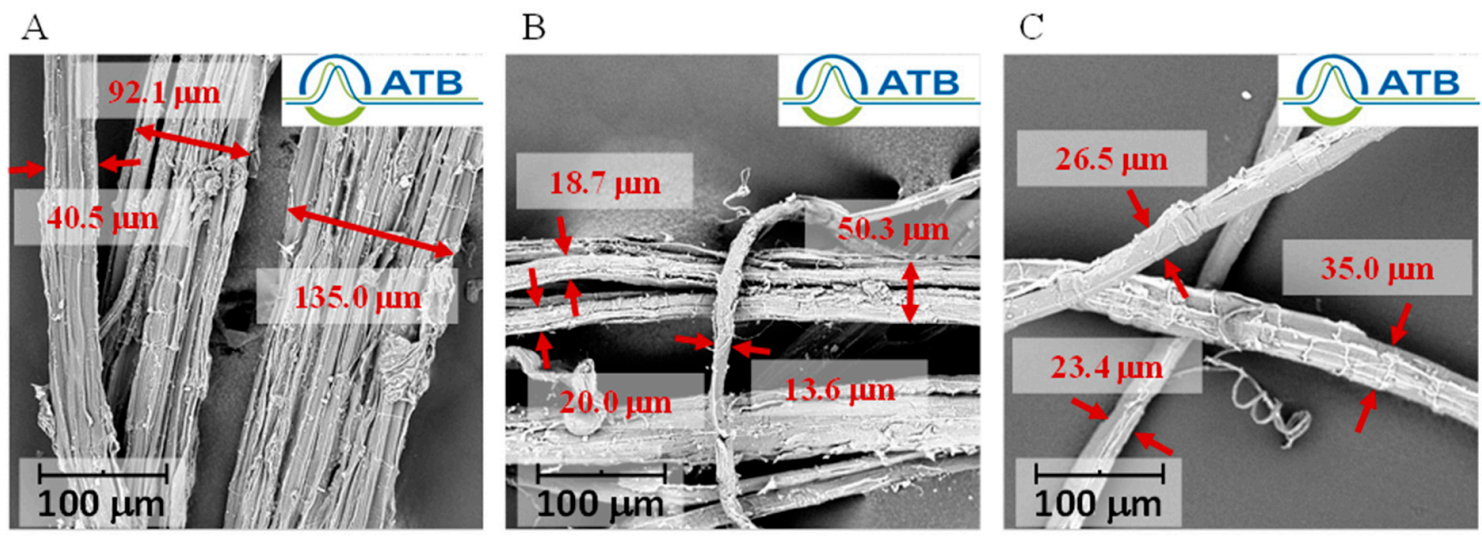

Figure 4. SEM images $(10 \mathrm{kV})$ of fresh chopped hemp whole crop material (A), wet preserved hemp whole crop material after a 1-month storage period (B), and wet preserved hemp whole crop material after 3-months of storage (C); details for bast and fibrous elements.

\subsection{Characterization of Intermediates and Final Products}

Ultimately, the usability and performance of raw materials is often also evaluated on the basis of the processability and relevant characteristic values of products. In this regard the characterization of test specimens took place in respective laboratories of partner institutions and the ATB according to generally admitted test norms and standards (Table 5).

Table 5. Methodical details for the analysis of composites and fiberboards.

\begin{tabular}{|c|c|c|c|c|}
\hline Material & Parameter & Unit & Methods & References \\
\hline \multirow[t]{2}{*}{$\begin{array}{l}\text { Natural fiber } \\
\text { reinforced } \\
\text { composites }\end{array}$} & $\begin{array}{l}\text { Tensile } \\
\text { modulus }\end{array}$ & $\mathrm{MPa}$ & $\begin{array}{l}\text { Tensile test of respective } \\
\text { specimens (rods) }\end{array}$ & $\begin{array}{c}\text { DIN EN ISO } \\
\text { 527-1:2012-06 [76] } \\
\text { DIN EN ISO } \\
\text { 527-4:1997-07 [77] }\end{array}$ \\
\hline & $\begin{array}{l}\text { Breaking } \\
\text { elongation }\end{array}$ & $\%$ & $\begin{array}{l}\text { Tensile test of respective } \\
\text { specimens (rods) }\end{array}$ & $\begin{array}{c}\text { DIN EN ISO } \\
\text { 527-1:2012-06 [76] } \\
\text { DIN EN ISO } \\
\text { 527-4:1997-07 [77] }\end{array}$ \\
\hline \multirow[t]{2}{*}{ Fiberboards } & Tensile strength & $\mathrm{MPa}$ * & $\begin{array}{l}\text { Tensile test } \\
\text { perpendicular to the } \\
\text { plane of the board }\end{array}$ & $\begin{array}{c}\text { DIN EN 319:1993 } \\
\text { [78] }\end{array}$ \\
\hline & $\begin{array}{l}\text { Modulus of } \\
\text { elasticity in } \\
\text { bending }\end{array}$ & $\mathrm{MPa}$ * & Three-point bending test & $\begin{array}{l}\text { DIN EN 310:1993 } \\
\text { [79] }\end{array}$ \\
\hline
\end{tabular}

* Values are given in $\mathrm{MPa}$ (variation of cited literature $[12,13]$ as well as referred standard where $\mathrm{N} \mathrm{mm}^{-2}$ is defined as respective unit for mechanical properties of fiberboards).

\section{Results on Processing and Products}

In order to carry out detailed research on the further processing of wet preserved (as well freshly chopped) hemp whole crop material, a pilot plant was established at the ATB beginning in 2007 [80,81]. 
Its initial step to processing includes the technical possibility to mix different types of raw material as well as treatment with steam. Subsequently, the material is fed into a processing unit called a defibration extruder. The technical principle of the unit is comparable to widely used equipment in the plastic industry, where two screws transport and exposure the fed with mechanical energy in a defined process area. Mainly pressure, shear load, and to some extent temperature, enable the decomposition of the initial structure of the wet preserved hemp material. A defibration of the bast, fiber bundles and xylem (woody core) textures becomes possible due to the previous degradation of cell wall components in the course of wet preservation. While a slight reduction of the moisture content of the intermediate is possible already in this procedure step, it is subsequently further processed with a disc mill aiming at an additional reduction of the particle size as well as at an equalization of the particle size distribution (Figure 5). This is to some extent comparable to refining processes in the wood panel industry, even if atmospheric process conditions and a much higher DM content of the fed prevail here. Various operating parameters can be set in order to a) react to specific properties of the fed material; and/or b) influence the selected quality parameters of the resulting intermediate $[74,82,83]$.

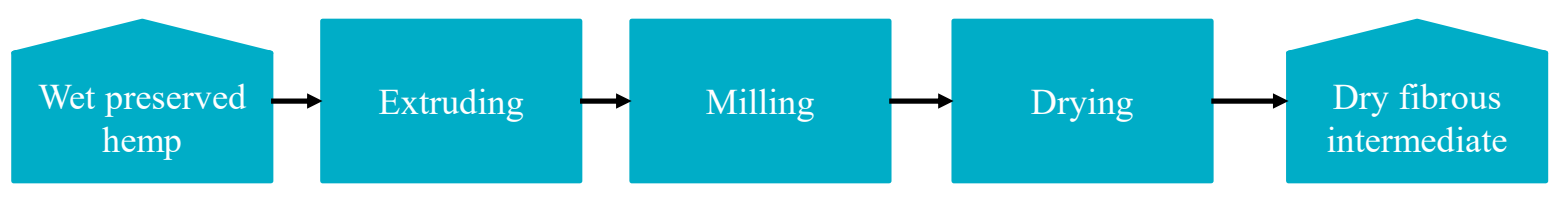

Figure 5. Main steps for the processing of wet preserved hemp raw materials in the Leibniz Institute for Agricultural Engineering and Bioeconomy (ATB) pilot plant.

After milling, the moisture content of the fibrous intermediate is reduced to approximately $10 \%$ by means of a flash dryer at an inlet air temperature of approximately $140{ }^{\circ} \mathrm{C}$. Further modifications of the geometric properties of the intermediate product can be achieved by mechanical or aero-dynamic screening. Thus, a transportable and storable intermediate product is available for further processing into composite materials or fiberboards.

Processing into intermediates (like compounds or fiber mat) and products (composites or fiberboards) was carried out partly by project partners or in the ATB pilot plant.

\subsection{Composites Reinforced with Fibrous Intermediates from Wet Preservation}

\subsubsection{Raw Materials and Composites Processing}

Hemp has been cultivated and further handled according the above mentioned procedure steps within the frame of the national collaborative network "FENAFA" in order to provide samples of fibrous intermediates for the manufacturing of natural fiber reinforced composites. All essential steps for the production of compounds and further processing by injection molding were carried out by the project partner, the Department of Lightweight Structures and Polymer Technology at the Technische Universität Chemnitz [74,82].

The selected results will show the influence of the different supply and processing procedures for wet preserved hemp on the properties of the composites. The matrix material used in all experiments was $68 \%$ polypropylene copolymer BE170MO (Borealis A/E) with $2 \%$ coupling agent SCONA TPPP 8112 (BYK-Chemie $\mathrm{GmbH}$ ). A 30\% mass proportion has been selected for the fibers added. The fibrous intermediate and the polymer component were processed to granulate using a Noris Plastic ZSC 25/44D twin-screw compounder. Arburgs's All Drive 370 injection molding machine was used to produce test rods from composite materials. The characterization of tensile properties of the test specimens was carried out by the project partner, the Department of Lightweight Structures and Polymer Technology at the Technische Universität Chemnitz on a material testing machine Zwick/Roell Z010 according to respective standard procedures (Table S1, Figures S1 and S2) [76,77]. 


\subsubsection{Selected Mechanical Properties of Composites}

One focus of detailed investigations has been the influence of ensiling additives in the hemp raw material on the resulting mechanical properties of composites. The processing of test specimens was carried out with fibrous intermediates of a previously 6 month wet preserved hemp of the variety Santhica 27 (Figure 6).

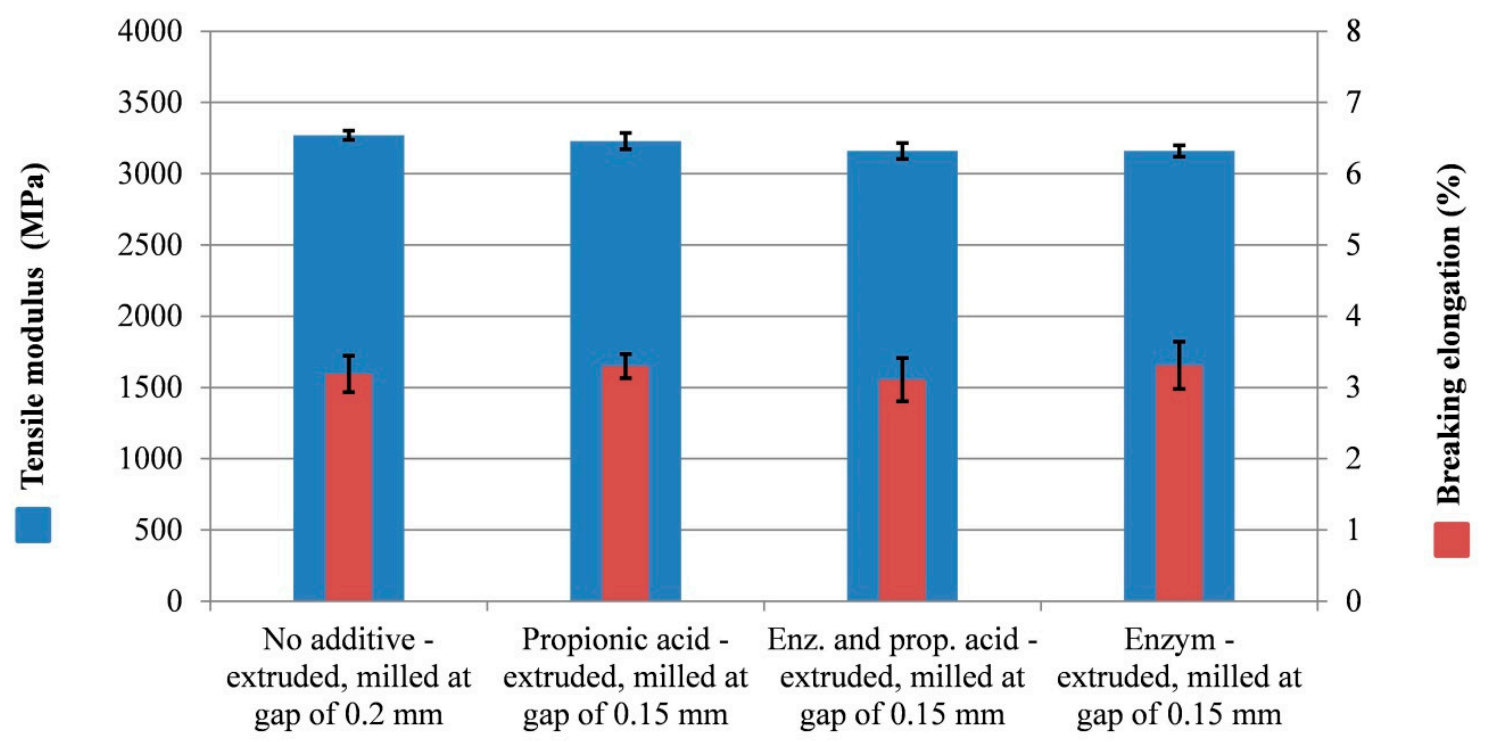

Figure 6. Mechanical properties of test samples manufactured from different fibrous intermediates, hemp variety Santhica 27, harvest 2011, processed after 6-months of storage.

The addition of ensiling additives, either acid or biological, seems to have no significant influence on the tensile modulus of thermoplastic based composite test specimens. A slight decrease can be observed when a pure enzyme solution in combination with propionic acid is added to the stored raw material. In contrast, the trend of elongation at break is contrary, but also not on a significant level.

Further investigations aimed at clarifying the influence of different processing methods on composites properties (Figure 7). These were carried out with raw material of the hemp variety USO-34 after a 6 month storage period as well. No ensiling agents were added to the crop. Cultivation and harvest took place in 2010.

By trend, it becomes clear that processing steps additional to extruding do not improve the stiffness of composite test specimens. In this case, this leads to the conclusion that a significant step towards decomposition of the natural tissue bonds in fiber bast and xylem has already occurred in the first processing step. The following mechanical or thermo-mechanical processes do not lead to changes in the properties of the fiber particles, resulting in an improvement of the mechanical properties of the composite materials.

The values found for the tensile modulus of the test samples in both experimental series are in range or even above results of other investigations carried out using comparable polymer reinforcement procedures, such as the compounding of (modified) Polypropylene copolymer with $30 \%$ hemp fibers and subsequent injection molding [84-87].

Although the levels of high-performance composites are not reached, a suitable reinforcing material can be supplied by this alternative raw material production line. Previous investigations have already shown that reinforcements are possible with fibrous raw materials based on wet preservation of hemp on a similar level compared to fibers produced by dry line [74]. A further experimental question was dedicated to the processing of whole plant materials using a single-stage process on a semi-industrial scale. Test specimens of natural reinforced composites have resulted from the direct processing of fibrous intermediates on an Injection Molding Compounder of KraussMaffei 
(KM 1300-14,000 IMC), available in the Pilot Plant of the Fraunhofer Institute for Mechanics of Materials (IWM). However, the results were somewhat $20 \%$ below the characteristic values of the investigations presented here [82].

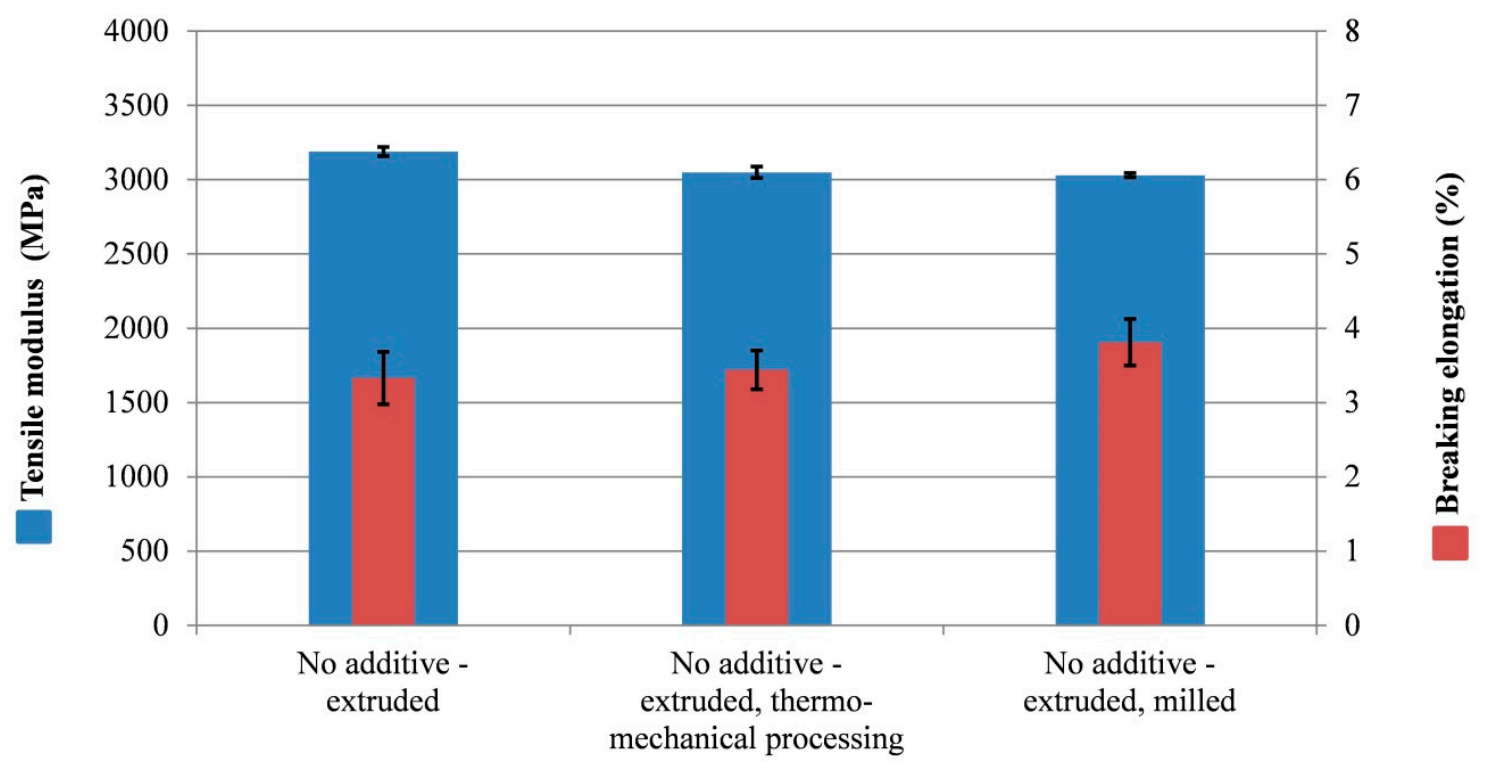

Figure 7. Mechanical properties of test samples manufactured from different fibrous intermediates, hemp variety USO-34, harvest 2010, processed after 6-months storage.

\subsection{Fiberboards Manufactured from Wet Preserved Hemp}

Hemp (Cannabis sativa L.) was grown at the experimental plot of the ATB in the course of research and demonstration activities of the EU project "MultiHemp" in 2014 (Table 2). The aim was to show that fibrous intermediates prepared in the dry/half-dry procedure from wet preserved hemp are suitable for the production of fiberboards for industrial applications.

\subsubsection{Raw Material and Preparation}

A French variety Futura 75, has been chosen from a variety trail covered in work package 3 ("Optimization of hemp cultivation and crop modelling") of EU project "MultiHemp". The harvest was carried out 23 September 2014 by means of a forage harvester (chopper) mounted to a tractor. Thereby the crop is cut into particles of approximately $50 \mathrm{~mm}$, which enables a proper densification of the harvested material. The densified biomass was sealed with silage wrapping immediately (Figure 2). The bales were stored under ambient conditions without additives for 17 months before processing. A detailed description of all the essential operating parameters for extruding, milling and drying have been described in detail in Lühr et al. [83].

It is known from the literature that an increased content of fine particles and dust in the fibrous intermediate can lead to reduced strength properties in the pressed fiberboards $[88,89]$. For this reason, in addition to the standard intermediate produced in the dry/half-dry procedure, another dust-free experimental series was prepared by screening (reciprocating screen, round-hole sieve $0.9 \mathrm{~mm}$ ).

A detailed particle analysis of the two intermediate test series with the image analysis system FibreShape (IST AG, Vilters, Switzerland) [90] shows as probability the frequency distribution $\mathrm{q}$ and the sum function $\mathrm{Q}$ for the width (Figure $8 \mathrm{~A}$ ) and in for the length (Figure $8 \mathrm{~B}$ ) of the particles. Four individual images of each series have been captured representing the image and subsequent particle size distribution analysis of all 20,000-150,000 particles. The samples have been scanned on a flatbed Epson Perfection 4870 PHOTO (Seiko Epson K.K., Suwa, Japan) at a resolution of 1200 dpi. Scanner software Silverfast SE (LaserSoft Imaging AG, Kiel, Germany) was used to process the image data. The necessary settings of the algorithm and the software parameters are saved in a specific file 
(measuring mask). A specified standard mask for given resolution was used with modified settings for the minimum object size $(20 \mu \mathrm{m})$ and a "zoom factor" (value 0.7$)$. This enables the automated stepwise measurement of fine up to larger objects in the same image.

A

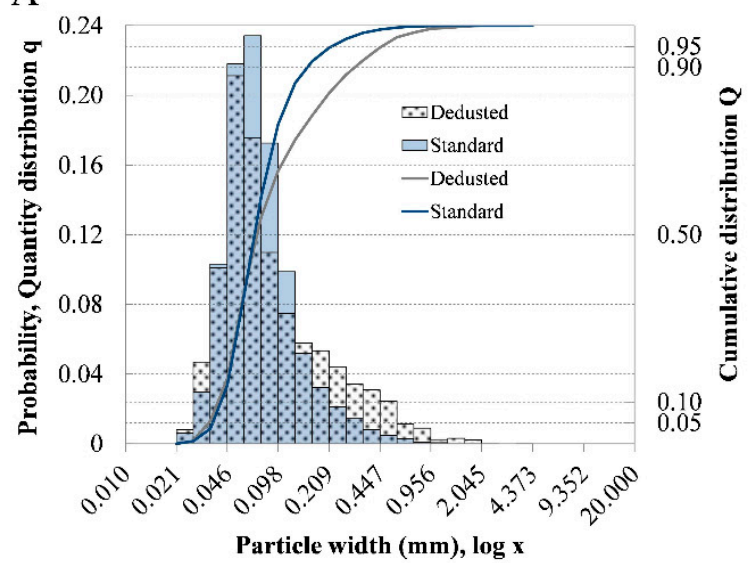

B

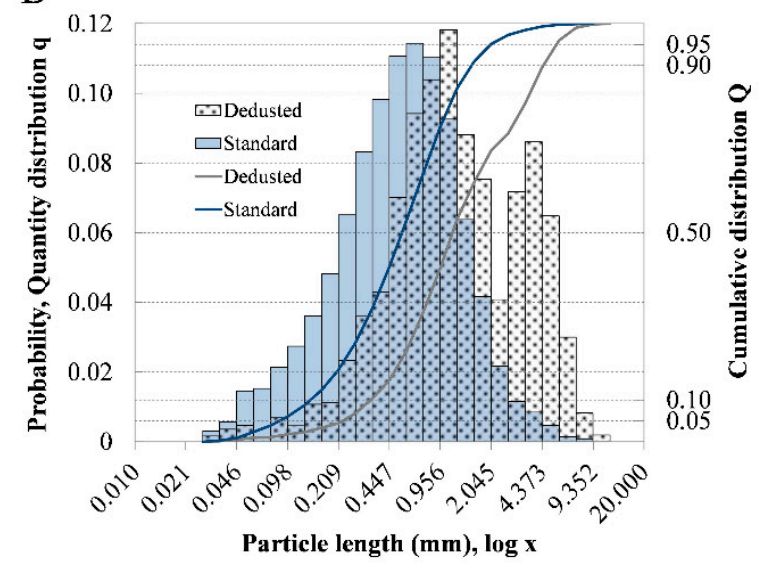

Figure 8. Evaluation of geometrical dimensions (A) width and (B) length of fibrous particles after processing, Futura 75 as well additional dedusting, resulting from an automated cumulative analysis of four scanned pictures (1200 dpi) using FibreShape.

In the "standard version" a width of $0.0672 \mathrm{~mm}$ and a length of $0.5324 \mathrm{~mm}$ were determined for the particle characteristic value median $\mathrm{d} 50$. In the "dedusted version", the width $0.0718 \mathrm{~mm}$ and the length $1.1549 \mathrm{~mm}$ were each determined as median d50 after screening out very small particles. The width d50 thus remained almost unchanged, whereby the length $\mathrm{d} 50$ is more than doubled. Thus the aspect ratio increased from 7.9 (standard) to 16.1 (dedusted) due to removal of fines (dust) by screening.

\subsubsection{Manufacturing of Fiberboards}

Two different fiberboard densities $\left(500 \mathrm{~kg} \mathrm{~m}^{-3} / 750 \mathrm{~kg} \mathrm{~m}^{-3}\right)$ were produced based on the two different fibrous intermediates (standard/dedusted). At the same time, it was examined whether the strength properties of the materials, which are reduced by increased dust content in the standard fiber material, could be compensated by an increase in the proportion of glue.

The further processing of the fibrous intermediates to fiberboards was realized by adding a standard glue. A prototype of a mixing machine, based on a rotating paddle and spray nozzles, was used to apply the glue to the fibrous intermediates in a batch process [91]. Urea-Formaldehyde resin ( $64 \%$ solid content) was used as adhesive with an amount of $10 \%$ (standard and dedusted versions) respectively $20 \%$ (standard version) solid content per absolutely dry fiber material, which is described as a gluing factor [92]. The hardening of the adhesive was accelerated by combination with Ammonium sulphate solution as hardener (33\% solid content) with an amount of $2 \%$ solid per solid content of adhesive. In order to avoid the boards being fractured in the cross cut due to too high a moisture content during hot pressing, the pulp was pre-dried from approximately $10 \%$ to approximately $5 \%$ moisture before gluing. Moisture contents $(\mathrm{H})$ of the specimens have been calculated according to Equation (1):

$$
H=\frac{m_{H}-m_{0}}{m_{0}} \cdot 100(\%)
$$

whereby is

- $m_{H}$ mass of test specimen at normal climate $(\mathrm{g})$

- $m_{0}$ mass of test specimen after drying $(\mathrm{g})$

With a gluing factor of $10 / 20 \%$, a moisture content of the glued fiber material of approximately $10 / 14 \%$ could be achieved. 
The fiberboards were produced on a path-controlled heating press in a three-stage pressing process. In this way, a higher and more uniform density should be achieved inside the boards. In order to evaporate water from the board and thus avoid plate bursting ("blistering") by resulting vapor pressure [93], an additional de-aeration phase was integrated into the operational system of the press. A detailed description of the individual press regimes for the respective density levels can be found in Lühr et al. [83].

The classification of the produced fiberboards was carried out to the initial norm DIN EN 316 (prior its update in 2009) [94] as is still commonly used in related industries. The boards were classified according to their density. Thus, boards with a density of $500 \mathrm{~kg} \mathrm{~m}^{-3}$ were assigned as ultralight fiberboards (UL-MDF) and boards with a density of $750 \mathrm{~kg} \mathrm{~m}^{-3}$ were assigned to medium density fiberboards (MDF).

\subsubsection{Characterization}

The characterization of the classified boards was carried out according the requirements for UL-FF as well as MDF for non-loading and general applications in dry environment [95]. In addition, ultralight fiberboards are subdivided according to their requirements in this standard into:

- $\quad$ UL1-MDF (usually used as insulation boards with limited mechanical stiffness) and

- UL2-MDF (typically used as panels with a stiffening function. These products also have insulating properties).

A detailed visual observation of the micro-structure of board samples by SEM (Figure 9A) enables a clear distinction of bast based (fiber) as well as xylem based (shive) particles.

A

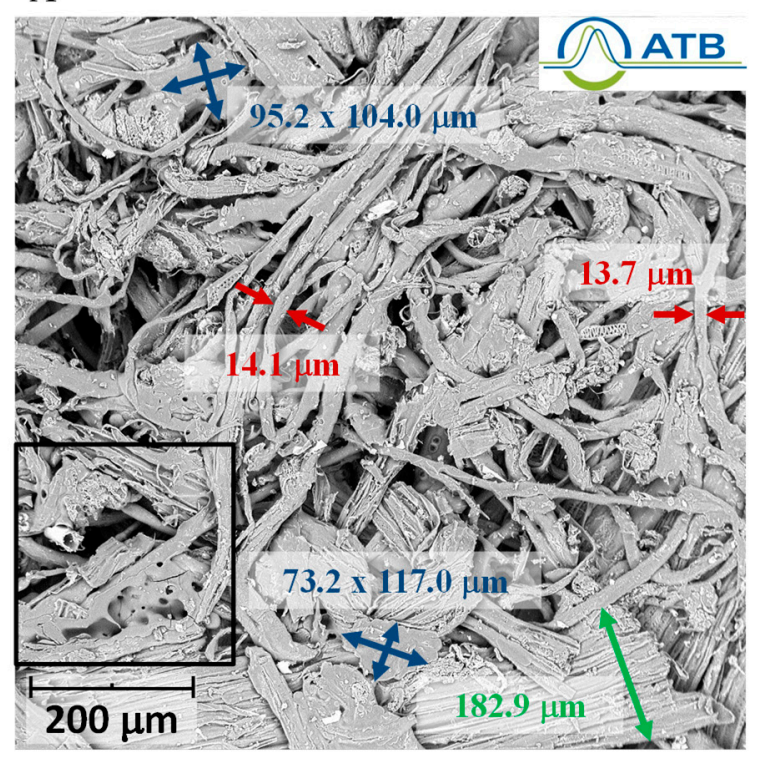

B

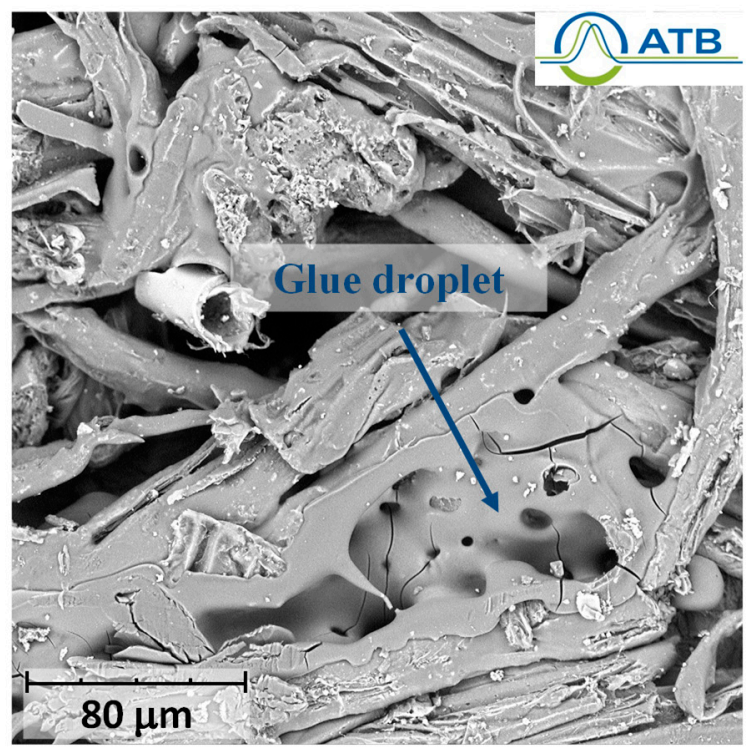

Figure 9. SEM images $(10 \mathrm{kV})$ of internal board structure, dedusted version with $10 \%$ gluing factor, target density $750 \mathrm{~kg} \mathrm{~m}^{-3}$ (black square at $\mathbf{A}$ in detailed image $\mathbf{B}$ ).

The width dimensions of the fibers $(13.7 ; 14.1 \mu \mathrm{m}$, red values) allow the conclusion that both the wet preservation as well as the mechanical processing lead to separation of the bast down to single fiber cell elements [75]. Larger particles in the composite are usually shives fragments, in the present case with a width of $182.9 \mu \mathrm{m}$ (green value). Even partially existing larger fiber structures (e.g., bundles, Figure $4 \mathrm{~B}$ ) can be processed to smaller particles by extruding and milling. Additionally, the SEM picture illustrates the random arrangement of particles in the board cross section as it is expected from the preparation of the prefabricate (fleece mat). Glue droplets can also clearly be distinguished by SEM 
microscopy of board samples. The measured dimensions (95.2; $117.0 \mu \mathrm{m}$, blue values) are in range of targeted sizes as it was modelled and applied for the design of the prototype mixing machine in the ATB's pilot plant [91]. Furthermore, in Figure 9B, a good wetting of the particles by a "glue droplet" for the transmission of the tension forces [96] is realized. It can be assumed that very fine glue droplets have been evenly distributed in the fibrous intermediate prior forming the prefabricate.

Test specimens were taken from the pressed boards according to a slicing scheme and the strength properties thereof were tested using a Zwick/Roell Z010 material testing machine with a load cell of $10 \mathrm{kN}$. The test speed was adjusted to reach the breaking force within the time limit of $(60 \pm 30) \mathrm{s}$ (Table S2, Figure S3) $[78,79,83]$.

Significantly higher values of tensile strength perpendicular to the plane of the board have been identified for test specimens manufactured from the dedusted material compared to the standard material in respective of density test series (Figure 10). This can be related to the reduced proportion of ultra-fine particles and dust. The higher aspect ratio in the dust-free intermediate also has a positive effect on strength properties of the test specimens.

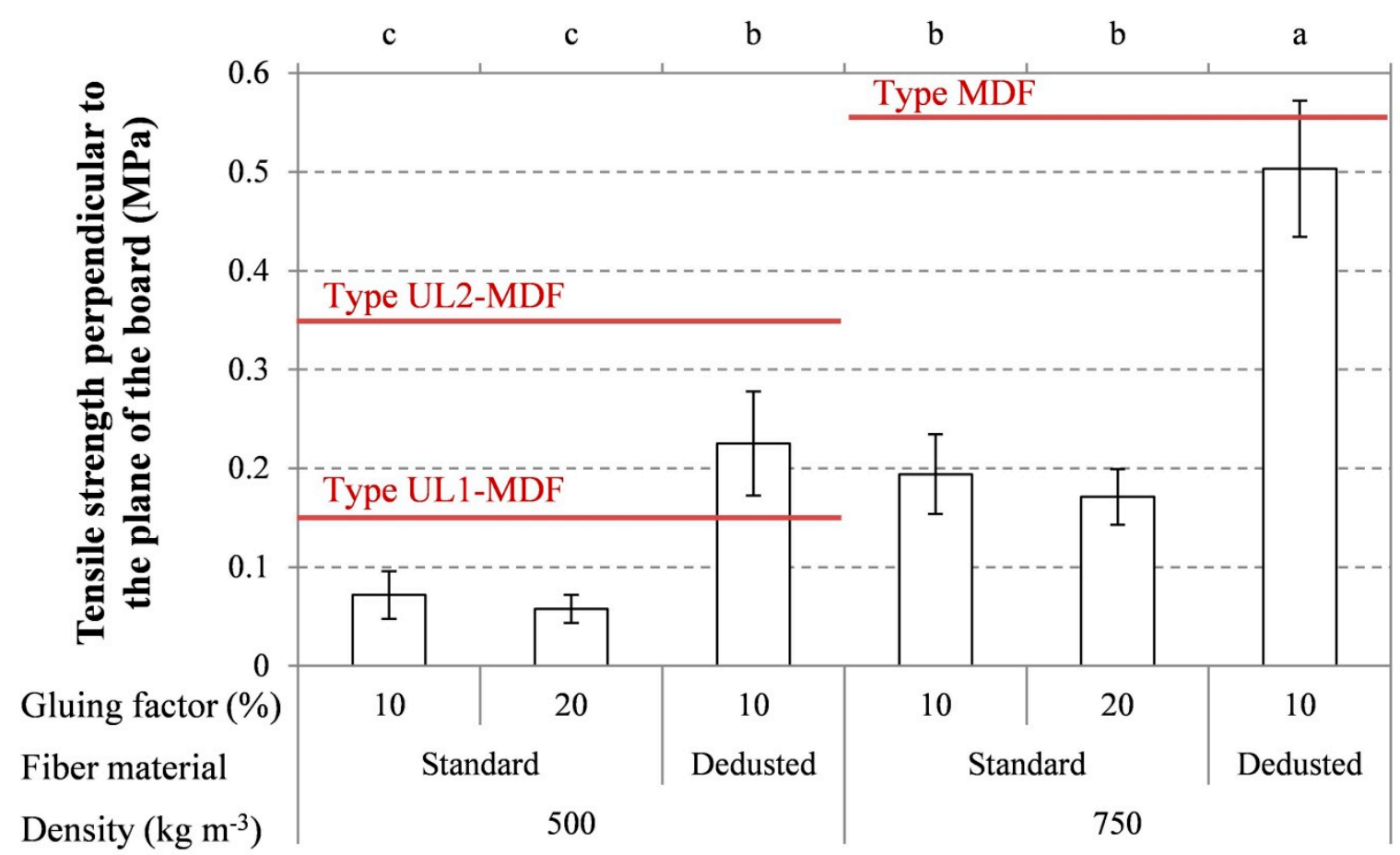

Figure 10. Effects of density, fiber material and gluing factor on tensile strength perpendicular to the plane of the board. Number of test specimen $n=10$. Different letters indicate significant differences (GLIMMIX, $p<0.05$ ). Values for density $500 / 750 \mathrm{~kg} \mathrm{~m}^{-3}$, fiber material standard and gluing factor $10 \%$ already published in Lühr et al. [83]. MDF-medium density fiberboards; UL-MDF-ultralight fiberboards.

No significant difference could be found between the different gluing factors of the standard fibrous material within the respective density level. However, values of tensile strength perpendicular to the plane of the board decrease slightly at a gluing factor of $10 \%$ to at a gluing factor of $20 \%$ by tendency. This can be attributed to the increased gluing factor and the thus reduced mass fraction of the fibers responsible for the tensile properties. The requirements of the boards with a density of $500 \mathrm{~kg} \mathrm{~m}^{-3}$ for type UL1-MDF can be met for the dust-free version. For samples with a density of $750 \mathrm{~kg} \mathrm{~m}^{-3}$, the requirements for the MDF type are only narrowly missed by the dust-free version. The test specimens of the dedusted series show the significantly highest value for both density levels.

Fracture layers as a result of the respective test procedure have been considered in order to investigate and evaluate their occurrence along the cross section of the test specimens. In addition, 
conclusions are possible regarding the process-related reasons for their emergence. Lühr et al. [83] developed a scheme for assessing the fracture layers in course of the determination of tensile strength perpendicular to the plane of the board. The test specimens were fixed with the upper side in the sample holders at any time and the respective failure frequencies were evaluated (Table 6).

Table 6. Distribution of failure frequencies regarding fracture layers after stress of tensile strength perpendicular to the plane. Number of test specimens $n=10 ; \mathrm{Ct}-\mathrm{Cap}$ area (top), T-Top area, $\mathrm{M}$-Middle, B-Bottom area, $\mathrm{Cb}$-Cap area (bottom). Values for density 500/750 $\mathrm{kg} \mathrm{m}^{-3}$, fiber material standard and gluing factor $10 \%$ already published in Lühr et al. [83].

\begin{tabular}{cccc}
\hline Density $\left(\mathbf{k g ~ m}^{-\mathbf{3}}\right)$ & Fiber Material & Gluing Factor $\mathbf{( \% )}$ & $\mathbf{C t} / \mathbf{T} / \mathbf{M} / \mathbf{B} / \mathbf{C b}$ \\
\hline 500 & Standard & 10 & $0 / 1 / 0 / 8 / 1$ \\
500 & Standard & 20 & $0 / 0 / 10 / 0 / 0$ \\
500 & Dedusted & 10 & $0 / 4 / 0 / 6 / 0$ \\
750 & Standard & 10 & $0 / 0 / 0 / 0 / 10$ \\
750 & Standard & 20 & $0 / 0 / 10 / 0 / 0$ \\
750 & Dedusted & 10 & $0 / 5 / 0 / 5 / 0$ \\
\hline
\end{tabular}

Different scenarios of the fracture behavior within the respective density level can be detected. The test specimens of the "standard version" with a density of $750 \mathrm{~kg} \mathrm{~m}^{-3}$ show $100 \%$ failure in the bottom cap area. The fine fraction drifts into the lower area of the board due to the gravimetric segregation of the fibrous intermediate in course of prefabricate forming. Accordingly, this leads to premature failure in this area and results in low tensile strength perpendicular to the plane due to the strength-reducing behavior of this particle fraction. The tear off in the bottom cap area could be avoided by increasing the proportion of adhesive in the panels to $20 \%$. However, due to the lack of fiber content in favor of the adhesive in the board, breakage occurred in the middle at a similarly low level of tensile strength perpendicular to the plane. The test specimens of the dust-reduced boards with a gluing factor of $10 \%$ (maximum values of tensile strength in both density levels) do not show premature failure in both of the top layers. With a two-stage pressing process, a bulk density profile with more intensive compression zones in the "cap area" or "middle" and those with low values in the "upper" or "lower area" is formed [89,97]. A failure of the board samples under transverse tensile stress in the range of low bulk densities is probable [98] and explains the distribution of failure frequencies. Obviously, the specified operational parameters of the press program enabled an optimum gross density profile with resulting high tensile strengths perpendicular to the plane.

Significantly higher values of modulus of elasticity in bending have been identified for test specimens with the density $750 \mathrm{~kg} \mathrm{~m}^{-3}$ compared to those with a density of $500 \mathrm{~kg} \mathrm{~m}^{-3}$ (Figure 11).

Here, the test specimens of the dedusted test series show the significantly highest values in both density levels, as well. Similar to the results of the tensile strength perpendicular to the plane, boards with a density of $500 \mathrm{~kg} \mathrm{~m}^{-3}$ almost achieved the requirements for type UL1-MDF for the dust-removed test series. In contrast, the requirements for the MDF type are clearly missed by the dust-free version at a density of $750 \mathrm{~kg} \mathrm{~m}^{-3}$.

It was shown that dust reduction in the fibrous intermediate and the related increase of the aspect ratio resulted in increased strength values. These are well above the values of an investigation aiming at the comparison of the varieties Bialobrzeskie and Futura 75 [83]. In this study, different processing procedures for wet preserved hemp from Bialobrzeskie and Futura 75 were considered in detail. The differences in the board strengths achieved are significantly smaller than those achieved with the modification of a fibrous intermediate carried out here. An increase in the gluing factor showed no positive effects. Moreover, in view of ecological, resource-saving board production, this is not an option for upgrading inferior fiber raw materials. 


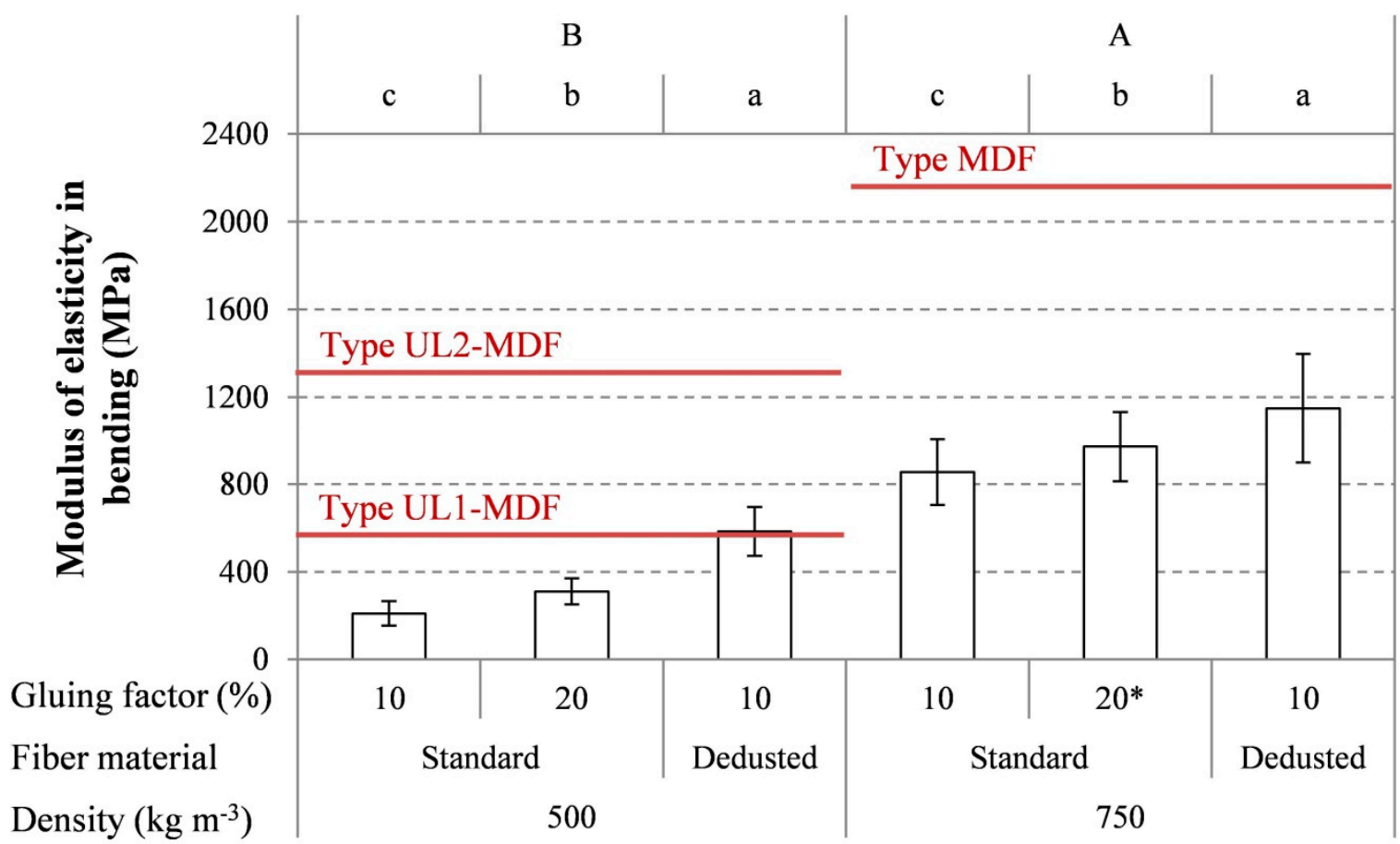

Figure 11. Effects of density, fiber material and gluing factor on modulus of elasticity in bending. Number of test specimen $n=10\left({ }^{*} n=9\right)$. Different letters indicate significant differences (SAS-GLIMMIX, $p<0.05$ ). Values for density $500 / 750 \mathrm{~kg} \mathrm{~m}^{-3}$, fiber material standard and gluing factor $10 \%$ already published in Lühr et al. [83].

\section{Discussion and Conclusions}

Direct harvesting of hemp by chopping, and the subsequent storage as well as wet preservation are easy to handle processes from the point of view of agricultural production and with regard to the available technical equipment at a farm level. The immediate removal of the crop enables farmers to take advantage from the superior pro-crop characteristic of growing hemp in a crop rotation. Furthermore, the weather related procedure risk is significantly reduced by a higher number of available field working hours for harvest operations. The known unpredictability of common field retting can be avoided.

If hemp is to be wet preserved, a harvest period between August and September with regard to the sugar content and dry matter content is suitable for many varieties. It is possible to produce stable preserved material from hemp chaff with low mass losses. The use of additives is not necessary for the preservation; however, some additives can make it possible to achieve selected changes of fiber properties. High contents of VFA, butyric acid or/and alcohol in the preserved hemp do not lead per se to high odor concentrations and unpleasant odors. During the aerobic storage, changes in the geometric and mechanical properties of the fibers occur.

The fibrous intermediate produced from wet preserved hemp represents a suitable raw material for the production of industrial goods like reinforced composites or fiberboards. Process technologies that are common in the composite industry can be used without constraints if feeding technology for bulk fibrous materials is available. The resulting properties are in the range of other materials processed with similar composition and technology. As an example, comparable investigations with PP (polypropylene) composites reinforced with as well 30\% hemp fiber are referred. Shah 2014 [4] reported in a comprehensive review of tensile modulus of $1500 \mathrm{MPa}$ for injection molded short fiber pellets. Higher values of $4000 \mathrm{MPa}$ have been reached by reinforcing such a matrix with $30 \%$ of hemp short fibers [99].

Furthermore, wet preserved hemp whole crop material can be processed to a fibrous intermediate by the innovative dry/half-dry procedure, suitable for the manufacturing of fiberboards similar to 
those produced by the conventional wood industry. The DIN-EN 622-5 [95] based requirements for industrial UL-MDF fiberboards have already been partially met by modifying the fibrous material using dust separation. In order to comply with the standards of especially commercially available MDF-type fiberboards, further optimization of the dry/semi-dry process with adapted particle size distributions of the fibrous intermediates and adaptions of the pressing regime are to be aimed at. Similar experimental work with sunflower stalks as raw material for particleboards bond with PMDI (polymeric methylene diphenyl diisocyanate) at a density of $650 \mathrm{~kg} \mathrm{~m}^{-3}$ resulted in comparable values of tensile strength perpendicular to the plane of the board (0.31-0.43 MPa) [13]. It is worth noting that, in principle, isocyanate based binder systems enable better mechanical properties of fiberor particleboards compared to UF (urea formaldehyde) or PF (phenol formaldehyde). In contrast, higher tensile strength perpendicular to the plane of the board $(0.93 \mathrm{MPa})$ but similar moduli of elasticity (1300 MPa) have been reached using palm tree prunings pressed at similar conditions with UF resin [12]. Thus, the high strength potential of hemp based whole crop materials is evident.

Another interesting challenge is the use of a formaldehyde-free adhesive system. This is the subject of current research at the ATB aiming at improving board properties to achieve all the required strength values.

Supplementary Materials: The following are available online at http://www.mdpi.com/2077-0472/9/7/140/s1, Table S1: Methodical details for the manufacturing and characterization of composite test specimens, Figure S1: Tensile curves of mechanical testing of test samples manufactured from different fibrous intermediates, hemp variety Santhica 27, harvest 2011, processed after 6-months storage, Figure S2: Tensile curves of mechanical testing of test samples manufactured from different fibrous intermediates, hemp variety USO-34, harvest 2010, processed after 6-months storage, Table S2: Methodical details for the manufacturing and characterization of fiberboard test specimens, Figure S3: Tensile curves of mechanical testing of modulus of elasticity in bending of test samples depending on density, fiber material and gluing factor.

Author Contributions: H.-J.G. and T.H. performed measurements and analyses, derived the equations, drew the figures, and wrote the introduction and the chapter on growing and harvesting. H.-J.G. performed analysis and wrote the paper on composites. C.I. performed the measurements and analyses, derived the equations, drew the figures, and wrote the chapter on wet preservation. C.L. performed the measurements and analyses, derived the equations, drew the figures, and wrote the chapter on fiber boards. R.P. supervised and reviewed the analysis and the full paper.

Funding: The authors gratefully acknowledge the funding by German Ministry of Food and Agriculture (BMEL) and its funding body Agency of Renewable Raw Materials (FNR) under grants 22023808, 22025608, 22025708 and 22025508. Further parts of research work were supported by MultiHemp project (Multipurpose hemp for industrial bioproducts and biomass), funded by European Union's Seventh Framework Programme for Research, Technological Development and Demonstration under grant agreement no. 311849.

Conflicts of Interest: The authors declare that the research was conducted in the absence of any commercial or financial relationships that could be construed as a potential conflict of interest.

\section{References}

1. Kymäläinen, H.R.; Sjöberg, A.M. Flax and hemp fibres as raw materials for thermal insulations. Build. Environ. 2008, 43, 1261-1269. [CrossRef]

2. Faruk, O.; Bledzki, A.K.; Fink, H.-P.; Sain, M. Biocomposites reinforced with natural fibres: 2000-2010. Prog Polym Sci. 2012, 37, 1552-1596. [CrossRef]

3. Gomina, M. Flax and hemp composite applications. In Flax and Hemp Fibres: A natural Solution for the Composite Industry; Reux, F., Verpoest, I., Eds.; JEC Composites: Paris, France, 2012; pp. 141-162, ISBN 978-2-9526276-0-1.

4. Shah, D.U. Natural fibre composites: Comprehensive Ashby-type materials selection charts. Mater. Des. 2014, 62, 21-31. [CrossRef]

5. Pil, L.; Bensadoun, F.; Pariset, J.; Verpoest, I. Why are designers fascinated by flax and hemp fibre composites? Compos. Part A Appl. Sci. 2015, 83, 193-205. [CrossRef]

6. Van Eynde, H. Comparative Life Cycle Assessment of Hemp and Cotton Fibres Used in Chinese Textile Manufacturing. Master thesis, University of Leuven, Leuven, Belgium, 2015. Available online: https: //www.scriptiebank.be/sites/default/files/VanEyndeHannes_KUL_Eindwerk.pdf (accessed on 28 May 2018). 
7. Brzyski, P.; Barnat-Hunek, D.; Suchorab, Z.; Łagód, G. Composite materials based on hemp and flax for low-energy buildings. Materials 2017, 10, 510. [CrossRef]

8. Placet, V.; François, C.; Day, A.; Beaugrand, J.; Ouagne, P. Industrial hemp transformation for composite applications: Influence of processing parameters on the fibre properties. In Advances in Natural Fibre Composites; Fangueiro, R., Rana, S., Eds.; Springer International Publishing: Cham, Switzerland, 2018; pp. 13-25.

9. Stevulova, N.; Cigasova, J.; Schwarzova, I.; Sicakova, A.; Junak, J. Sustainable bio-aggregate-based composites containing hemp hurds and alternative binder. Buildings 2018, 8, 25. [CrossRef]

10. Kremensas, A.; Kairytė, A.; Vaitkus, S.; Vejjelis, S.; Balčiūnas, G. Mechanical performance of biodegradable thermoplastic polymer-based biocomposite boards from hemp shivs and corn starch for the building industry. Materials 2019, 12, 845. [CrossRef]

11. Hegazy, S.S.; Ahmed, K. Effect of date palm cultivar, particle size, panel density and hot water extraction on particleboards manufactured from date palm fronds. Agriculture 2015, 5, 267-285. [CrossRef]

12. Ferrández-García, C.-E.; Ferrández-García, A.; Ferrández-Villena, M.; Hidalgo-Cordero, J.F.; García-Ortuño, T.; Ferrández-García, M.-T. Physical and mechanical properties of particleboard made from palm tree prunings. Forests 2018, 9, 755. [CrossRef]

13. Papadopoulos, A.N.; Kyzas, G.Z.; Mitropoulos, A.C. Lignocellulosic composites from acetylated sunflower stalks. Appl. Sci. 2019, 9, 646. [CrossRef]

14. Uitterhaegen, E.; Labonne, L.; Merah, O.; Talou, T.; Ballas, S.; Véronèse, T.; Evon, P. Impact of thermomechanical fiber pre-treatment using twin-screw extrusion on the production and properties of renewable binderless coriander fiberboards. Int. J. Mol. Sci. 2017, 18, 1539. [CrossRef] [PubMed]

15. Amaducci, S.; Scordia, D.; Liu, F.H.; Zhang, Q.; Guo, H.; Testa, G.; Cosentino, S.L. Key cultivation techniques for hemp in Europe and China. Ind. Crops Prod. 2015, 68, 2-16. [CrossRef]

16. Salentijn, E.; Zhang, Q.; Amaducci, S.; Yang, M.; Trindade, L. New developments in fibre hemp (Cannabis sativa L.) breeding. Ind. Crops Prod. 2014, 68, 32-41. [CrossRef]

17. Carus, M. The Reintroduction of Industrial Hemp is in Full Swing Worldwide. Press Release of the European Industrial Hemp Association (EIHA). Available online: http://news.bio-based.eu/media/2018/05/18-05-17PR-EIHA-Award-and-Conference.pdf (accessed on 8 June 2018).

18. Carus, M.; Eder, A.; Dammer, L.; Korte, H.; Scholz, L.; Essel, R.; Breitmayer, E. WPC/NFC Market Study 2014-03 Wood-Plastic Composites (WPC) and Natural Fibre Composites (NFC): European and Global Markets 2012 and Future Trends; Nova-Institut: Hürth, Germany, 2014.

19. Westerhuis, W. Hemp for Textiles: Plant Size Matters. PhD Thesis, Wageningen University, Wageningen, The Netherlands, 2016.

20. Dickeduisberg, M.; Beckhaus, H. Hemp in Germany-Renaissance as winter cover crop for high quality textile hemp-fibres. In Proceedings of the 14th International Conference of the European Industrial Hemp Association (EIHA), Cologne, Germany, 7-8 June 2017.

21. Moussa, T.; Maalouf, C.; Ingrao, C.; Scrucca, F.; Costantine, G.; Asdrubali, F. Bio-based and recycled-waste materials in buildings: A study of energy performance of hemp-lime concrete and recycled-polyethylene terephthalate façades for office facilities in France and Italy. Sci. Technol. Built Environ. 2018, 24, 492-501. [CrossRef]

22. Viel, M.; Collet, F.; Lanos, C. Chemical and multi-physical characterization of agro-resources' by-product as a possible raw building material. Ind. Crops Prod. 2018, 120, 214-237. [CrossRef]

23. Amaducci, S.; Gusovius, H.-J. Hemp-Cultivation, extraction and processing. In Industrial Applications of Natural Fibres; Stevens, C.V., Müssig, J., Eds.; Wiley \& Sons Ltd.: London, UK, 2010.

24. Bouloc, P.; Allegret, S.; Arnaud, L. Hemp: Industrial Production and Uses; CABI: Wallingford, UK, 2013 ; p. 313.

25. Pari, L.; Baraniecki, P.; Kaniewski, R.; Scarfone, A. Harvesting strategies of bast fibre crops in Europe and in China. Ind. Crops Prod. 2015, 68, 90-96. [CrossRef]

26. Gusovius, H.-J.; Hoffmann, T.; Budde, J.; Lühr, C. Still special? Harvesting procedures for industrial hemp. Landtechnik 2016, 71, 14-24. [CrossRef]

27. Hernandez-Estrada, A.; Gusovius, H.-J.; Müssig, J.; Hughes, M. Assessing the susceptibility of hemp fibre to the formation of dislocations during processing. Ind. Crops Prod. 2016, 85, 382-388. [CrossRef] 
28. Wang, S.; Gusovius, H.-J.; Lühr, C.; Musio, S.; Uhrlaub, B.; Amaducci, S.; Müssig, J. Assessment system to characterise and compare different hemp varieties based on a developed lab-scaled decortication system. Ind. Crops Prod. 2018, 117, 159-168. [CrossRef]

29. Müssig, J.; Amaducci, S. Scanner based image analysis to characterise the influence of agronomic factors on hemp (Cannabis sativa L.) fibre width. Ind. Crops Prod. 2018, 113, 28-37. [CrossRef]

30. Sisti, L.; Totaro, G.; Vannini, M.; Celli, A. Retting process as a pretreatment of natural fibres for the development of polymer composites. In Lignocellulosic Composite Materials; Kalia, S., Ed.; Springer: Cham, Switzerland, 2018; pp. 97-135.

31. Sharma, H.S.S.; Lefevre, J.; Boucaud, J. Role of microbial enzymes during retting and their effect on fibre characteristics. In The biology and processing of flax; Sharma, H.S.S., Ed.; M Publications: Belfast, UK, 1992; pp. 199-212. ISBN 978-0951996300.

32. Bacci, L.; Lonardo, S.; Albanese, L.; Mastromei, G.; Perito, B. Effect of different extraction methods on fibre quality of nettle (Urtica Dioica, L.). Text. Res. J. 2010, 81, 827-837. [CrossRef]

33. Akin, D.E. Linen most useful: Perspective on structure, chemistry and enzyme for the retting flax. ISRN Biotechnol. 2013, 1-23. [CrossRef] [PubMed]

34. Ribeiro, A.; Pochart, P.; Day, A.; Mennuni, S.; Bono, P.; Baret, J.L.; Spadoni, J.L.; Mangin, I. Microbial diversity observed during hemp retting. Appl. Microb. Biotechnol. 2015, 99, 4471-4484. [CrossRef] [PubMed]

35. Jankauskienè, Z.; Butkutè, B.; Gruzdevienè, E.; Cesevičienė, J.; Fernando, A.-L. Chemical composition and physical properties of dew- and water-retted hemp fibres. Ind. Crops Prod. 2015, 75, 206-211. [CrossRef]

36. Liu, M.; Fernando, D.; Daniel, G.; Madsen, B.; Meyer, A.S.; Ale, M.T.; Thygesen, A. Effect of harvest time and field retting duration on the chemical composition, morphology and mechanical properties of hemp fibres. Ind. Crops Prod. 2015, 69, 29-39. [CrossRef]

37. Placet, V.; Day, A.; Beaugrand, J. The influence of unintended field retting on the physicochemical and mechanical properties of industrial hemp bast fibres. J. Mater. Sci. 2017, 52, 5759-5777. [CrossRef]

38. Bleuze, L.; Lashermes, G.; Alavoine, G.; Recous, S.; Chabbert, B. Tracking the dynamics of hemp dew retting under controlled environmental conditions. Ind. Crops Prod. 2018, 123, 55-63. [CrossRef]

39. Mazian, B.; Bergeret, A.; Benezet, J.C.; Malhautier, L. Influence of field retting duration on the biochemical, microstructural, thermal and mechanical properties of hemp fibres harvested at the beginning of flowering. Ind. Crops Prod. 2018, 116, 170-181. [CrossRef]

40. Idler, C.; Ehlert, D.; Ackermann, I.; Kühne, G. Ernte, Konservierung und Erstverarbeitung von Hanf aus Einer Feuchtgutlinie, Harvesting, Conservation and First Processing of Hemp from a Moist Material Line. ATB-Projektabschlußbericht 2000/3; Institut für Agrartechnik: Potsdam, Germany, 2000; p. 43, In German.

41. De Maeyer, E.A.A.; Huisman, W. New technology to harvest and store fibre hemp for paper pulp. J. Int Hemp Assoc. 1994, 1, 38-41.

42. De Maeyer, E.A.A.; Huisman, W. Growing fibre hemp for pulp and paper: A new approach to harvesting and processing. In Alternative Oilseed and Fibre Crops for Cool and Wet Regions of Europe, Proccedings of the COST 814 Workshop Proc., Wageningen, The Netherlands, 7-8 April 1994; COST 814 Workshop Proc.: Wageningen, The Netherlands, 1994; pp. 157-162. Available online: http://edepot.wur.nl/412578 (accessed on 1 July 2018).

43. De Maeyer, E.A.A.; Huisman, W. Oogst en Conserveringstechniek van Vezelhennep, Techniques for Harvesting and Storage of Fibre Hemp; IMAG-DLO and Wageningen Agricultural University: Wageningen, The Netherlands, 1995; p. 138, in Dutch with English summary.

44. Einsiedel, R.; Bayer, R.; von Buttlar, H.B.; Scheffer, K. Fibres and composites from hemp silage. In Biomass for Energy and Industry, Proceedings of the 10th International Conference; Kopetz, H., Weber, T., Palz, W., Chartier, P., Ferrero, G.L., Eds.; Carmen Publ.: Würzburg, Germany, 1998; pp. 509-510.

45. Hartinger, T.; Gresner, N.; Südekum, K.-H. Effect of wilting intensity, dry matter content and sugar addition on nitrogen fractions in lucerne silages. Agriculture 2019, 9, 11. [CrossRef]

46. Szlachta, J.; Prask, H.; Fugol, M.; Luberański, A. Effect of mechanical pre-treatment of the agricultural substrates on yield of biogas and kinetics of anaerobic digestion. Sustainability 2018, 10, 3669. [CrossRef]

47. Idler, C.; Pecenka, R.; Fürll, C.; Gusovius, H.-J. Wet processing of hemp: An overview. J. Nat. Fibers 2011, 8, 59-80. [CrossRef]

48. Pecenka, R.; Idler, C.; Grundmann, P.; Fürll, C.; Gusovius, H.-J. Tube ensiling of hemp-Initial practical experience. Agric. Eng. Res. 2007, 13, 15-26. [CrossRef] 
49. Tahir, P.M.; Ahmed, A.A.; SaifulAzry, S.O.; Ahmed, Z. Retting process of some bast plant fibres and its effect on fibre quality: A review. BioResources 2011, 6, 5260-5281. [CrossRef]

50. Gusovius, H.-J.; Prochnow, A.; Streßmann, U.; Hahn, J. The weather-determined process risk of harvesting fibre hemp. In Proceedings of the International Conference on Agricultural Engineering, Part 2, Warwick, UK, 2-7 July 2000; pp. 46-48.

51. Hoffmann, T.; Pecenka, R.; Schemel, H.; Gusovius, H.-J. Process-technological evaluation of harvesting hemp in winter. J. Nat. Fibres 2013, 10, 159-175. [CrossRef]

52. Pasila, A. The Dry-Line Method in Bast Fibre Production. Academic Dissertation, University of Helsinki, Faculty of Agriculture and Forestry, Helsinki, Finland, 2004.

53. KTBL. Betriebsplanung Landwirtschaft 2016/17-Operational Planning in Agriculture; 25. Auflage; KTBL: Darmstadt, Germany, 2016; p. 768. ISBN 978-3-945088-19-7. In German.

54. MultiHemp Deliverables Rated Public to Public. Available online: http://multihemp.eu/project/publicdeliverables. (accessed on 5 July 2018).

55. Wieringa, G.W.; Haan, S. Inkuillen-Ensiling; IBVL: Wageningen, The Netherlands, 1961; In Dutch.

56. Mc Donald, P.; Henderson, A.R.; Heron, S.J.E. The Biochemistry of Silage, 2nd ed.; Marlow, Chalcombe Publication: Southampton, UK, 1991; p. 340. ISBN 978-0948617225.

57. Akin, D.E.; Foulk, J.A.; Dodd, R.B.; McAlister III, D.D. Enzyme-retting of flax and characterization of processed fibers. J. Biotechnol. 2001, 89, 193-203. [CrossRef]

58. Di Candilo, M.; Bonatti, P.M.; Guidetti, C.; Focher, B.; Grippo, C.; Tamburini, E.; Mastromei, G. Effects of selected pectinolytic bacterial strains on water-retting of hemp and fibre properties. J. Appl. Microbiol. 2010, 108, 194-203. [CrossRef]

59. Fuentes, C.A.; Willekens, P.; Petit, J.; Thouminot, C.; Müssig, J.; Trindade, L.M.; Van Vuure, A.W. Effect of the middle lamella biochemical composition on the non-linear behaviour of technical fibres of hemp under tensile loading using strain mapping. Compos. Part A Appl. Sci. 2017, 101, 529-542. [CrossRef]

60. Dreyer, J.; Müssig, J.; Koschke, N.; Ibenthal, W.-D.; Harig, H. Comparison of enzymatically separated hemp and nettle fibre to chemically separated and steam exploded hemp fibre. J. Ind. Hemp 2008, 7, 43-59. [CrossRef]

61. DLG-Ausschuss für Futterkonservierung. Praxishandbuch Futter- und Substratkonservierung-Practical Manual for Feed and Substrate Conservation; 8. Auflage; DLG German Agricultural Society: Frankfurt, Germany, 2012; In German.

62. VDLUFA. Die Chemische Untersuchung von Futtermitteln-The Chemical Analyses of Forage. Methodenbuch; Band III., 3. Auflage; 6. Ergänzungslieferung; VDLUFA-Verlag: Darmstadt, Germany, 2006.

63. Herrmann, C.; Heiermann, M.; Idler, C.; Prochnow, A. Particle size reduction during harvesting of crop feedstock for biogas production: 1. Effects on ensiling process and me-thane yield. BioEnergy Res. 2012, 102, 5153-5161. [CrossRef]

64. Herrmann, C.; Heiermann, M.; Idler, C. Effects of ensiling, silage additives and storage period on methane formation of biogas crops. Bioresour. Technol. 2011, 102, 5153-5161. [CrossRef] [PubMed]

65. Weissbach, F.; Kuhla, S. Stoffverluste bei der Bestimmung des Trockemassegehaltes von Silagen und Grünfutter. Entstehende Fehler und Möglichkeiten der Korrektur-Losses in determining the dry matter content of silages and green fodder. Errors and possibilities of correction. Übersicht Tierernährung 1995, 23, 189-214, In German.

66. Huisman, W.; Mayer, E.; Frerichs, L. Harvest and storage of hemp. In Proceedings of the Symposium “Bioressource Hemp", Frankfurt, Germany, 2-5 May 1995.

67. Cappelletto, P.; Brizzi, M.; Mongardini, F.; Barberi, B.; Sannibale, M.; Nenci, G. Italy-grown hemp: Yield, composition and cannabinoid content. Ind. Crops Prod. 2001, 13, 101-113. [CrossRef]

68. Van der Werf, H.M.G.; Van Geel, W.C. Fibre Hemp as Raw Material for Paper. Agronomic Research 1990-1993. Verslag; Proefstation voor de Akkerbouw en de Groenteteelt in de Vollegrond: Lelystad, The Netherlands, 1994; Volume 177, p. 68.

69. Liu, M.; Thygesen, A.; Summerscales, J.; Meyer, A.S. Targeted pre-treatment of hemp bast fibres for optimal performance in biocomposite materials: A review. Ind. Crops Prod. 2017, 108, 660-683. [CrossRef]

70. Fischer, H.; Gerardi, H.; Knittel, D.; Antonov, V. Removal of odour from bast fibres in industrial scale by chemical and enzymatic treatment. In Proceedings of the 15th international conference STRUTEX, Technical University of Liberec, Liberec, Czech Republic, 1-3 December 2008; pp. 331-338. 
71. FNR. Schlussbericht zum Vorhaben Thema: FENAFA-Netzwerkverbund-Teilvorhaben 3: Zielgerichtete Weiterentwicklung und Anpassung der Verfahrensschritte zur Bereitstellung und Konditionierung von Naturfaserkonservat für den Einsatz in Verbundwerkstoffen (Schwerpunkt: Hanf), Final report on the Project Topic: FENAFA Network-Subproject 3: Targeted Further Development and Adaptation of the Process Steps for the Provision and Conditioning of Natural Fibre Conservation for Use in Composite Materials (Focus: Hemp). Available online: https://www.fnr.de/index.php?id=11150\&fkz=22023808 (accessed on 02.07.2018).

72. DIN EN. 13725:2003-07: Luftbeschaffenheit-Bestimmung der Geruchsstoffkonzentration mit dynamischer Olfaktometrie, Air quality - Determination of odour concentration by dynamic olfactometry; Beuth Verlag: Berlin, Germany, 2003; In German.

73. VDI. 3882 Blatt 1:1992-10. Olfaktometrie; Bestimmung der Geruchsintensität_Olfactometry; Determination of Odour Intensity; Beuth Verlag: Berlin, Germany, 1992; In German.

74. Wallot, G.; Gusovius, H.-J.; Pecenka, R.; Schierl, S.; Rinberg, R.; Nendel, W. Developments in the use of fibres from wet-preserved hemp for composite production. Agric. Eng. Int. CIGR J. 2012, 14, 218-223.

75. Müssig, J.; Fischer, H.; Graupner, N.; Drieling, A. Testing methods for measuring physical and mechanical fibre properties (plant and animal fibres). In Industrial Applications of Natural Fibres; Stevens, C.V., Müssig, J., Eds.; Wiley \& Sons Ltd.: London, UK, 2010.

76. DIN EN ISO 527-1:2012-06. Kunststoffe-Bestimmung der Zugeigenschaften-Teil 1: Allgemeine Grundsätze_Plastics_Determination of Tensile Properties_Part 1: General Principles; Beuth Verlag GmbH: Berlin, Germany, In German.

77. DIN EN ISO 527-4:1997-07. Kunststoffe-Bestimmung der Zugeigenschaften-Teil 4: Prüfbedingungen für isotrop und anisotrop faserverstärkte Kunststoffverbundwerkstoffe—Plastics—Determination of tensile properties_Part 4: Test Conditions for Isotropic and Anisotropic Fibre-Reinforced Plastic Composites; Beuth Verlag GmbH: Berlin, Germany, In German.

78. DIN EN 319:1993. Span- und Faserplatten-Bestimmung der Zugfestigkeit Senkrecht zur Plattenebene-Particleboards and fibreboards-Determination of Tensile Strength Perpendicular to the Plane of the Board; Beuth Verlag: Berlin, Germany, In German.

79. DIN EN 310:1993. Holzwerkstoffe-Bestimmung des Biege-Elastizitätsmoduls und der Biegefestigkeit-Wood-Based Panels_Determination of Modulus of Elasticity in Bending and of Bending Strength; Beuth Verlag: Berlin, Germany, In German.

80. Pecenka, R.; Fürll, C.; Idler, C.; Grundmann, P.; Radosavljevic, L. Fibre boards and composites from wet preserved hemp. Int. J. Mater. Prod. Technol. 2009, 36, 208-220. [CrossRef]

81. Gusovius, H.-J.; Pecenka, R.; Wallot, G.; Rinberg, R.; Nendel, W. An alternative processing technology for agricultural raw materials to supply fibrous materials for reinforced composites. In Proceedings of the BioComp 2010-10th Pacific Rim Bio-Based Composites Symposium, Banff, Canada, 5-8 October 2010.

82. Gusovius, H.-J.; Wallot, G.; Schierl, S.; Rinberg, R.; Hartmann, T.; Kroll, L.; Jahn, I. Processing of wet preserved natural fibres with injection molding compounding (IMC). In Natural Fibres: Advances in Science and Technology Towards Industrial Applications from Science to Market; Fangueiro, R., Rana, S., Eds.; Proceedings of the 2nd International Conference on Natural Fibres ICNF 2015; Springer International Publishing: Cham, Switzerland, 2016; pp. 197-210. ISBN 978-94-017-7513-7.

83. Lühr, C.; Pecenka, R.; Budde, J.; Hoffmann, T.; Gusovius, H.-J. Comparative investigations of fibreboards resulting from selected hemp varieties. Ind. Crops Prod. 2018, 118, 81-94. [CrossRef]

84. Ogazi-Onyemaechi, B.C.; Nakamura, M.; Kitagawa, K.; Ichikawa, I.; Akahoshi, I.; Sahoo, S.; Nakai, A.; Kotaki, M.; Ishiaku, U.S.; Hamada, H. Mechanical properties of hemp fibre/poly olefin composites by injection molding. In Proceedings of the 22nd Annual Meeting of the Polymer Processing Society, Yamagata, Japan, 2-6 July 2006. [CrossRef]

85. Tajvidi, M.; Motie, N.; Rassam, G.; Falk, R.H.; Felton, C. Mechanical performance of hemp fiber polypropylene composites at different operating temperatures. J. Reinf. Plast. Compos. 2010, 29, 664-674. [CrossRef]

86. Haag, K.; Müssig, J. Ergebnisse der Untersuchungen. In Entwicklung einer industriellen Naturfaser-Pellet-Produktion zur Nutzung von Naturfasern als Verstärkung von (Bio-) Kunststoffen in Spritzguss und Extrusion"-Results of the investigations. In Development of an industrial natural fibre pellet production for the use of natural fibres as reinforcement of (bio-) plastics in injection moulding and extrusion. Projektabschlussbericht 2012, (AZ: 27717-34). Available online: https: //www.dbu.de/OPAC/ab/DBU-Abschlussbericht-AZ-27717.pdf (accessed on 01 July 2018). In German. 
87. Pickering, K.L.; Aruan Efendy, M.G.; Le, T.M. A review of recent developments in natural fibre composites and their mechanical performance. Compos. Part A Appl. Sci. 2016, 83, 98-112. [CrossRef]

88. Kollmann, F. Holzspanwerkstoffe-Wood Chip Materials; Springer-Verlag: Berlin, Germany; Heidelberg, Germany; New York, NY, USA, 1966; p. 822, In German; ISBN 978-3-642-50247-7.

89. Dunky, M.; Niemz, P. Holzwerkstoffe und Leime: Technologie und Einflussfaktoren-Wood Based Panels and Resins: Technology and Influence Parameters; Springer-Verlag: Berlin-Heidelberg, Germany, 2002; p. 954, In German; ISBN 978-3-642-55938-9.

90. Müssig, J.; Schmid, H.G. Quality control of fibres along the value added chain by using scanning technique-From fibres to the final product. Microsc. Microanal. 2004, 10, 1332-1333. [CrossRef]

91. Radosavljević, L. Ressourcenschonende Herstellung hochwertiger Faserplatten aus Hanfsilage, Optimierung der Bindemittelapplikation-Resource-Saving Production of High-Quality Fibre Boards from Hemp Silage, Optimisation of Binder Application. Dissertation, Brandenburgische Technische Universität Cottbus. 2010. Available online: https:/opus4.kobv.de/opus4-btu/frontdoor/index/index/year/2010/docId/1742 (accessed on 05 July 2018). In German.

92. Pizzi, A. Wood and fibre panel technology. In Research Developments in Wood Engineering and Technology; Aguilera, A., Davim, J.P., Eds.; IGI Global: Hershey, PA, USA, 2014; pp. 46-89, ISBN 978-1466645547.

93. Ebnesajjad, S.; Landrock, A. Adhesives Technology Handbook; Elsevier Ltd.: Oxford, UK, 2014; p. 414, ISBN 978-0323355957.

94. DIN EN 316:1999-12. Holzfaserplatten—Definition, Klassifizierung und Kurzzeichen—Fibreboards—Definition, Classification and Abbreviations; Beuth Verlag: Berlin, Germany, In German.

95. DIN EN 622-5:2009-03. Anforderungen an Platten nach dem Trockenverfahren (MDF)—Requirements for Boards Using the Dry Process (MDF); Beuth Verlag: Berlin, Germany, In German.

96. Dunky, M. Adhesives in the wood industry. In Handbook of Adhesive Technology, 3rd ed.; Pizzi, A., Mittal, K.L., Eds.; CRC Press: Boca Raton, FL, USA, 2018; pp. 511-574, ISBN-13: 9781498736442.

97. Gruchot, M. In-situ-Untersuchungen des Rohdichteprofils von Holzwerkstoffen am Beispiel von MDF-In-situ Investigations of the Density Profile of Wood Materials Using MDF as an Example. Ph.D. Thesis, Universität Hamburg, Hmaburg, Germany, 2009. In German.

98. Boehme, C. Die Bedeutung des Rohdichteprofils für MDF-The Importance of the Density Profile for MDF. Holz als Roh und Werkstoff 1992, 50, 18-24, In German. [CrossRef]

99. Baets, J. Semi-Products with Flax and Hemp Fibres. In Flax and Hemp Fibres: A natural Solution for the Composite Industry; Reux, F., Verpoest, I., Eds.; JEC Composites: Paris, France, 2012; pp. 87-117, ISBN 978-2-9526276-0-1. 